\title{
28. TECTONICS OF HESS DEEP: A SYNTHESIS OF DRILLING RESULTS FROM LEG 147'
}

\author{
C.J. MacLeod, ${ }^{2}$ B. Célérier, ${ }^{3}$ G.L. Früh-Green, ${ }^{4}$ and C.E. Manning ${ }^{5}$
}

\begin{abstract}
We present a synthesis of the tectonics of the Hess Deep rift valley, equatorial East Pacific Rise (EPR), as deduced from structural, paleomagnetic, petrological, geochemical, and borehole geophysical data acquired during Ocean Drilling Program (ODP) Leg 147. These data show that the crustal section and underlying shallow mantle lithologies now exposed in Hess Deep were formed by seafloor spreading at the north-south-trending EPR, were then transported eastward away from the EPR ridge axis, and became influenced by extensional tectonism caused by amagmatic rifting in advance of the westward-propagating Cocos-Nazca spreading center.

Seawater influx into layer 3, the plutonic portion of the oceanic crust, commenced soon after crystallization, with pervasive influx of water along randomly oriented microfracture networks and grain boundaries, mostly at temperatures of $600^{\circ}-750^{\circ} \mathrm{C}$. This permeability was probably created by tensile brittle failure upon subsolidus cooling and thermal contraction of the gabbro, and must have been established within several tens of thousands of years after axial magma emplacement and within a few kilometers of the ridge axis. When the upper plutonic section had cooled to a temperature of $\sim 450^{\circ} \mathrm{C}$, probably a few tens of kilometers from the EPR axis and tens to a couple of hundred thousand years after axial magmatism, it became influenced by the effects of Cocos-Nazca rifting, and a dense array of east-west tensile fractures developed. Widespread access of seawater to sub-Moho levels and consequent onset of serpentinization occurred at this time.

The ODP drill sites are located on an intra-rift horst block in the north of Hess Deep, and previous workers had speculated that serpentinite diapirism was responsible for the differential uplift of this block. However, textural evidence from the drill cores suggests that serpentinization of the shallow mantle there was a predominantly static phenomenon; hence, exhumation of the lower crust and shallow mantle appears to have taken place by block faulting rather than incoherent diapirism. Uplift of the intra-rift ridge was accommodated on normal cataclastic shear zones, which contain low-temperature mineral assemblages $\left(150^{\circ}-250^{\circ} \mathrm{C}\right)$, implying that uplift occurred at a relatively late stage.

Paleomagnetic data from the drillsites, fully restored to geographical coordinates, show that the intra-rift ridge has suffered significant tectonic rotation, with both a northward component of tilt and a counter-clockwise vertical-axis component of rotation. We do not have sufficient evidence to constrain unequivocally the axis or axes of rotation, but argue that compound rotations are likely in such a complex tectonic setting. In conjunction with other geophysical evidence from the Hess Deep area, we tentatively conclude that a counter-clockwise vertical-axis tectonic rotation occurred at a very early stage, perhaps in the overlap basin of the duelling propagators at $2^{\circ} \mathrm{N}$ on the EPR. At a later stage, and associated with the opening of the Hess Deep rift, northward tilting appears to have occurred (about a subhorizontal axis), as a result of rotational normal faulting above a southdipping detachment surface. Later, post-detachment normal faulting was probably responsible for the isolation and differential uplift of the intra-rift ridge.
\end{abstract}

\section{BACKGROUND Regional Setting}

Hess Deep is a 5400-m-deep fault-bounded basin, located at $2^{\circ} \mathrm{N}$, $101^{\circ} \mathrm{W}$, close to the boundary between the Pacific, Cocos, and Nazca plates in the eastern equatorial Pacific Ocean. The EPR and CocosNazca spreading axes do not physically meet at the triple junction; instead, a small microplate (the Galapagos microplate; Lonsdale, 1988) separates them (Fig. 1). The inferred position of the tip of the active Cocos-Nazca spreading ridge is some $60 \mathrm{~km}$ east of the present-day EPR axis (Fig. 2), and it is propagating westward at a rate comparable to the $65-\mathrm{km} / \mathrm{m}$.y. half-spreading rate of the EPR (Lonsdale, 1977, 1988; Hey et al., 1977; Searle and Francheteau, 1986). The Hess

'Mével, C., Gillis, K.M., Allan, J.F., and Meyer, P.S. (Eds.), 1996. Proc. ODP, Sci. Results, 147: College Station, TX (Ocean Drilling Program).

${ }^{2}$ Department of Earth Sciences, University of Wales College of Cardiff, P.O. Box 914, Cardiff CF1 3YE, United Kingdom. Formerly at: Institute of Oceanographic Sciences, Brook Road, Wormley, Surrey GU8 5UB, United Kingdom; and Borehole Research, Department of Geology, University of Leicester, Leicester LE1 7RH, United Kingdom.macleod@cardiff.ac.uk

${ }^{3}$ CNRS-URA 1767, Case Courrier 57, Université de Montpellier II, 34095 Montpellier cedex 05, France.

${ }^{4}$ Department of Earth Sciences, ETH-Zürich, CH-8092, Switzerland.

'Department of Earth and Space Sciences, University of California at Los Angeles, Los Angeles, CA 90024-1567, U.S.A.
Deep itself lies between the EPR and the Cocos-Nazca spreading ridge, and is a westward-migrating rift valley resulting from northsouth extension of the EPR flank ahead of the magmatically active Cocos-Nazca ridge; it can thus be regarded as the "tectonic tip" (Kleinrock and Hey, 1989) of the propagating Cocos-Nazca ridge. A major horst block, $8 \mathrm{~km}$ wide by $25 \mathrm{~km}$ long, flat-topped and eastwest elongate, occurs between the Cocos-Nazca axis and the northern scarp that bounds the valley (Fig. 2).

Submersible studies have shown that substantial sections of approximately 1-m.y.-old oceanic crust and shallow mantle from the EPR are exposed in the Hess Deep rift valley (Francheteau et al., 1990, 1992; Karson et al., 1992). In particular, they show that the scarps that bound the rift valley to the south and north expose complete, relatively fresh sections through volcanics, sheeted dikes, and high-level plutonics, and that the horst, or so-called "intra-rift ridge," and adjacent deep (the Hess Deep itself) are characterized by more tectonically disrupted sections of lavas, sheeted dikes, gabbros, and shallow-mantle peridotites (Fig. 3).

Tectonic disruption of the area is complex and cannot yet be deciphered unambiguously. Two alternative models for the formation of the intra-rift ridge within the Hess Deep rift valley have been proposed by Francheteau et al. (1990). One attributes formation of the ridge to diapiric uplift of serpentinized shallow mantle, the other to detachment faulting and block rotation on listric normal faults. These models, and possible alternatives, are discussed at the end of this paper in the light of the new information from Leg 147 presented here. 


\section{Present-day Tectonic Regime From Earthquake Focal Mechanisms}

The position of Hess Deep, at the tip of a propagating rift and close to the margin of a microplate, suggests that the tectonic setting and history of the area is likely to be complex (see Lonsdale, 1988). Because constraints on the present tectonic regime may help understand the recent past regime, we made a search in the published literature and Harvard CMT database for available fault plane solutions within the area of latitude $0^{\circ}$ to $8^{\circ} \mathrm{N}$ and longitude $105^{\circ} \mathrm{E}$ to $94^{\circ} \mathrm{E}$. This yielded 14 events between 1969 and 1989, which are listed in Table 1. The P, B, and T axes of each of these events are taken as an approximate indication of the principal stress directions $S_{1}, S_{2}, S_{3}$ (the maximum, intermediate, and minimum principal stress directions, respectively), an assumption that is reasonable in the vast majority of situations (Célérier, 1988), but can result in angular errors of up to $90^{\circ}$ (McKenzie, 1969) in unlikely cases. The axis with the largest plunge defines which of the principal stresses is vertical, and the orthogonal projection of the axis with the smallest plunge on the horizontal plane defines one of the horizontal principal stress directions, $\mathrm{S}_{h \max }$ or $\mathrm{S}_{h \min }$ (the maximum and minimum directions, respectively). For all of the events documented in the Pacific-Cocos-Nazca triple junction area, one of the principal stress directions remains within $18^{\circ}$ of the horizontal (Table 1), thus confirming that one principal stress direction is close to the vertical (Anderson, 1905). The resulting horizontal stress directions are mapped and displayed together with the seismic nodal planes on Figure 4.

Few intraplate events are recognized: three within the Pacific plate and only one within the Cocos plate. Despite the obvious complexity of the tectonic regime, events on the Pacific plate indicate a consistent northeast-southwest maximum horizontal principal stress direction, $\mathrm{S}_{H_{\max }}$ (Figs. 4, 5). Seven events occur on the Cocos-Nazca plate boundary: four of them indicate a wrench regime and three of them a normal regime; the normal regime events are located in eastern part of the area of interest. The minimum horizontal principal stress direction varies from event to event but remains within $30^{\circ}$ of the expected north-south extension direction suggested by the CocosNazca ridge trend. To decide whether this variation of direction is real or due to the misidentification of the stress direction with the $\mathrm{P}$, $\mathrm{B}$, and $\mathrm{T}$ axis requires more data and stress inversion techniques (e.g., Angelier, 1984). Three events are located on the Galapagos-Nazca boundary (Fig. 4); two of these are normal events corresponding to the Dietz Deep extensional boundary, the other is a strike-slip event corresponding to the strike-slip rift discussed by Lonsdale (1988).

All indications of present-day stress direction are compiled in Figure 5 , including (stress-induced?) borehole elongation data derived from the ODP drill sites (see below; Célérier et al., this volume). Both the focal mechanisms and the regional tectonics suggest that the state of stress around Hess Deep is heterogeneous and requires a finer scale study. The absolute plate directions from Hey et al. (1977) show no simple relationship with the compressional stress direction for our Pacific or Cocos data (Fig. 5). The minimum stress orientations are also compared with the preferential enlargement directions inferred from Hole 894G downhole logging data (Fig. 5; Célérier et al., this volume). These enlargement directions are poorly defined because of poor conditions in Hole 894G (see discussion in "Downhole Logging" section below); however, it is possible that the borehole enlargements trending approximately $030^{\circ}$ reflect some influence of the $020^{\circ}-030^{\circ}$ Cocos-Nazca $\mathrm{S}_{h \text { min }}$ direction that corresponds to the event closest to Hess Deep. Similarly, the $140^{\circ}-170^{\circ}$ azimuth enlargements could reflect the influence of the nearby Galapagos-Nazca strike-slip rift stress system or the Cocos-Nazca $140^{\circ}-170^{\circ} \mathrm{S}_{\text {/min }}$ direction farther east; however, this would imply that the $030^{\circ} \mathrm{Cocos}-$ Nazca $S_{h \min }$ direction does not affect Hess Deep. In all cases, the inferred strike slip tectonic regime would have helped borehole failure by enhancing the horizontal principal stress differences.

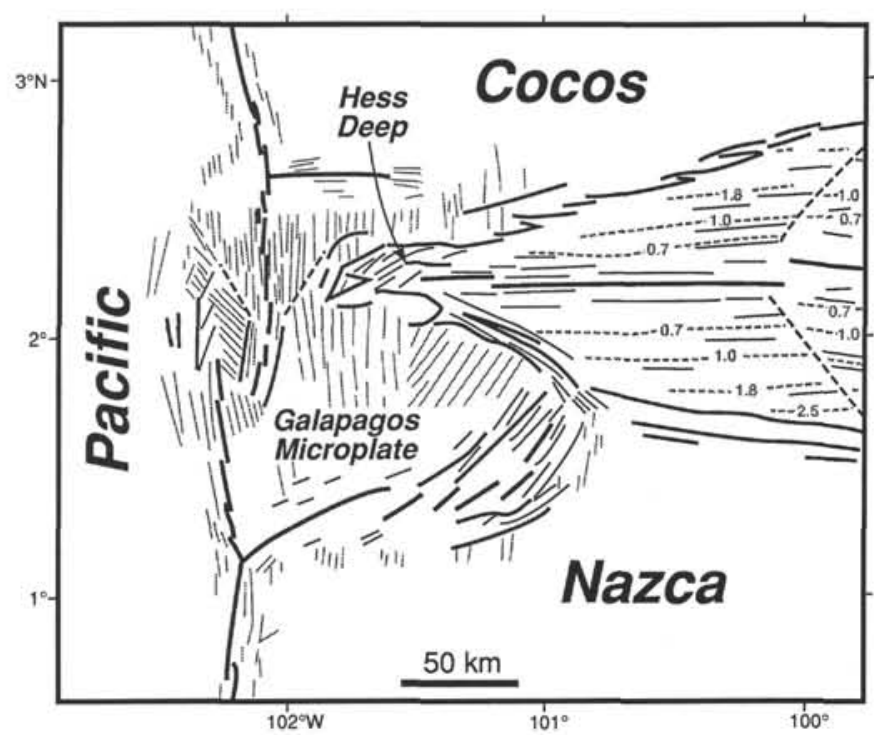

Figure 1. Morphotectonic map of the Galapagos microplate (after Lonsdale, 1988).

\section{ODP Drilling in Hess Deep}

Drilling investigations in Hess Deep during Leg 147 focused on the intra-rift ridge (Gillis, Mével, Allan, et al., 1993). Two sites were drilled (Figs. 2 and 3). The first, Site 894, is located near the summit of the western end of the ridge, at approximately $2^{\circ} 18.0^{\prime} \mathrm{N}$, $101^{\circ} 35.5^{\prime} \mathrm{W}$, in water depths of between $3023 \mathrm{~m}$ and $3044 \mathrm{~m}$. Holes $894 \mathrm{~A}-\mathrm{F}$ were either test holes or unsuccessful attempts to set the hard-rock guidebase; the principal hole, Hole $894 \mathrm{G}$, penetrated 154.5 $\mathrm{m}$ below seafloor (mbsf). At this site, minor thicknesses (a few meters) of sediment and basaltic cobbles covered a basement composed of gabbroic lithologies (described below). The second drill site, Site 895 , is located at $2^{\circ} 16.7^{\prime} \mathrm{N}, 101^{\circ} 26.7^{\prime} \mathrm{W}$, in water depths of $3692 \mathrm{~m}$ to $3820 \mathrm{~m}$, on the southern slope of the eastern end of the intra-rift ridge. Of the six holes drilled at this site, two (Holes 895D and $895 \mathrm{E}$ ) had substantial penetration (93.7 and $87.6 \mathrm{~m}$, respectively). Recovered rocks consist principally of partially serpentinized tectonized harzburgites and dunites, with lesser abundances of mafic lithologies.

\section{SITE 894 \\ Lithostratigraphy}

Gabbronorites form $80 \%$ of the recovered rock types in Hole $894 \mathrm{G}$. The remainder consists (in order of decreasing abundance) of basalt (from two basic dikes cutting the section), olivine gabbronorite, gabbro, and olivine gabbro. Because the subdivision of these lithologies has no significance for the tectonic evolution of the drill site, the plutonic rocks from Site 894 are henceforth referred to as gabbros.

Site 894 gabbros are not modally layered, and have grain sizes and textures that vary rapidly on short length scales. Throughout much of the Hole $894 \mathrm{G}$ section a near-vertical foliation and lineation could be recognized in the gabbros, defined by the shape-preferred orientation of anisometric plagioclase crystals. MacLeod and Boudier (1994) and MacLeod, Boudier, et al. (this volume) show that these fabrics were formed by magmatic flow, and that evidence for solid-state, ductile deformation is absent. Reorientation of these fabrics shows that the foliation originally paralleled the EPR axis. The complete lack of evidence for solid-state deformation at Site 894 is in marked contrast to the plutonic sections drilled in oceanic gabbro sections 


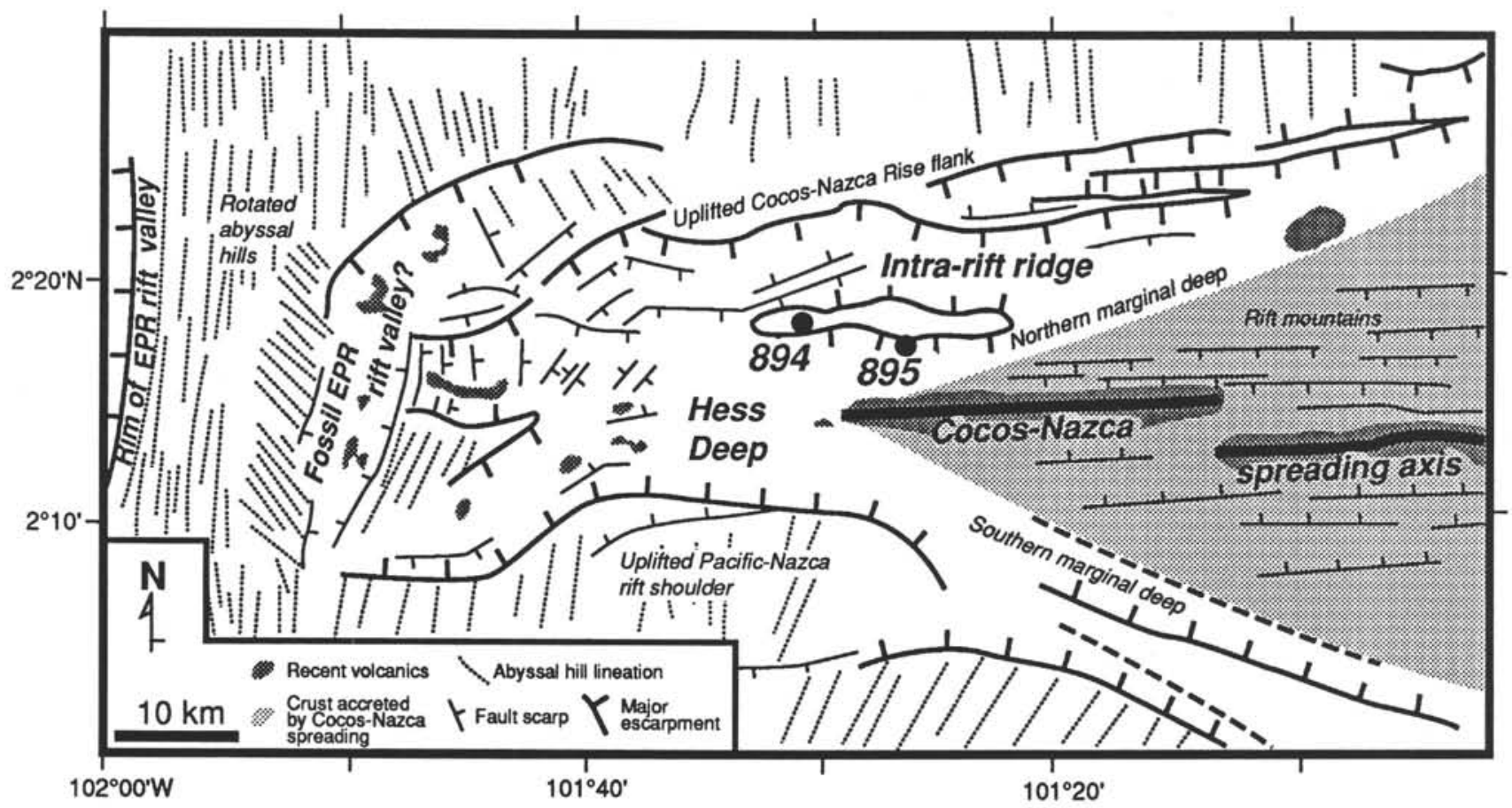

Figure 2. Morphotectonic map of Hess Deep, modified after Lonsdale (1988) with reference to GLORIA sidescan sonar imagery originally acquired by Searle and Francheteau (1986). ODP drill sites are marked. Note the regions of northwest-trending abyssal hill terrain (see "Discussion" section).

from slow-spreading ridges (Southwest Indian Ridge, Hole 735B: Dick et al., 1991; Mid-Atlantic Ridge at Kane: Cannat, Karson, Miller, et al., 1995), within which ductile deformation is common.

In order to determine the original stratigraphic position of the Site 894 section, Dick and Natland (1994), Natland and Dick (this volume), and Pedersen et al. (this volume) compare the compositions of the drilled gabbros with samples recovered by submersible from the north wall of the Hess Deep rift valley. They show that the drilled gabbros are similar in composition to those from the upper part of the plutonic ("layer 3") section, but that they are less evolved than the extremely fractionated lithologies recovered from slightly below the sheeted dike-gabbro transition. These highly fractionated rocks are interpreted by Dick and Natland (1994) as marking the position of the axial melt lens; hence the Site 894 section appears to be located slightly (tens to hundreds of meters) below this level, and at an original depth of crystallization of the gabbros of between $2 \mathrm{~km}$ and $3 \mathrm{~km}$ below the seafloor.

\section{Rock Magnetism}

Paleomagnetic measurements were made on drill core samples from Site 894 during Leg 147 (Gillis, Mével, Allan, et al., 1993) and post-cruise (Pariso et al., this volume; MacLeod, Manning, et al., this volume). Demagnetization of samples by either alternating field or thermal techniques led, in most cases, to the isolation of a stable remanent magnetization vector, carried by magnetite. This is assumed to be carried by small, secondary magnetite grains formed soon after crystallization of the gabbroic section, when it cooled to the Curie temperature of $550^{\circ}-580^{\circ} \mathrm{C}$ (Gillis, Mével, Allan, et al., 1993; Pariso et al., this volume). Inclinations of stable remanence vectors from the Hole $894 \mathrm{G}$ average $39.1^{\circ}$ downward $\left( \pm 17.6^{\circ} ; N=29\right.$; Fig. 6$)$, which is significantly different from that expected for the latitude of the drill site; assuming that the remanent magnetization was acquired in a geocentric dipole field, the inclination should be very shallow $\left(+4.6^{\circ}\right)$. This anomalous inclination is very unlikely to be a consequence of secular variations of the earth's field, which should cause no more than $13^{\circ}$ of angular dispersion (McFadden and Merrill, 1975) and should not be significant in such slowly cooled rocks; nei- ther can it be due to a change in latitude of the site (e.g., Lonsdale, 1988), or caused by deviation of the borehole (which is inclined at only $4^{\circ}$ from the vertical between $45 \mathrm{mbsf}$ and $80 \mathrm{mbsf}$; Célérier et al., this volume). The steep inclinations are therefore most readily interpreted in terms of a tectonic tilting of the section, by approximately $35^{\circ}$, subsequent to acquisition of its remanent magnetization close to the axis of the EPR. Any vertical component of rotation is not constrained by the magnetic data alone; and because the latitude of the Leg 147 drill sites is so low the paleomagnetic data by themselves are insufficient to determine whether the section is normally or reversely polarized. The Shipboard Scientific Party inferred a reverse polarity, by assuming the intra-rift ridge section to be similar to the $\sim 1 \mathrm{Ma}$ ages of the north and south flanks of Hess Deep at the longitude of the drill sites (Gillis, Mével, Allan, et al., 1993); Gee et al. (1992), however, report normal polarities from some lower crustal samples recovered by the ALVIN submersible. The polarity, age of the site, and axis and magnitude of tectonic rotation are discussed further in later sections of this paper.

\section{Cataclastic Deformation}

The only evidence for displacive deformation in Site 894 cores is the minor cataclasis observed in the $25-\mathrm{m}$ section of Hole $894 \mathrm{~F}$ and the uppermost $23 \mathrm{~m}$ of adjacent Hole $894 \mathrm{G}$. This cataclastic material forms less than $1 \%$ of the total recovered core from the site. The cataclastically deformed zones are heterogeneous on a centimeter scale with respect to grain size and degree of alteration. The degree of deformation is also variable, ranging from distributed bands of protocataclastic gabbro through to foliated cataclasites and ultracataclasites with increasing strain. The cataclasites and ultracataclasites may be foliated, with "S-C" fabrics, Riedel shear arrays and offsets of brittlely disaggregated clasts indicating normal shear senses in every observed instance (Gillis, Mével, Allan, et al., 1993). Microscopically, the fabrics are characterized by grain size reduction by microcracking of primary igneous phases, producing sub-rounded to angular porphyroclasts set in a fine-grained clast-clay matrix dominated by corrensite, a regular layered chlorite-smectite mineral (Früh-Green, Plas, and Dell'Angelo, this volume). The proportion of this matrix in- 


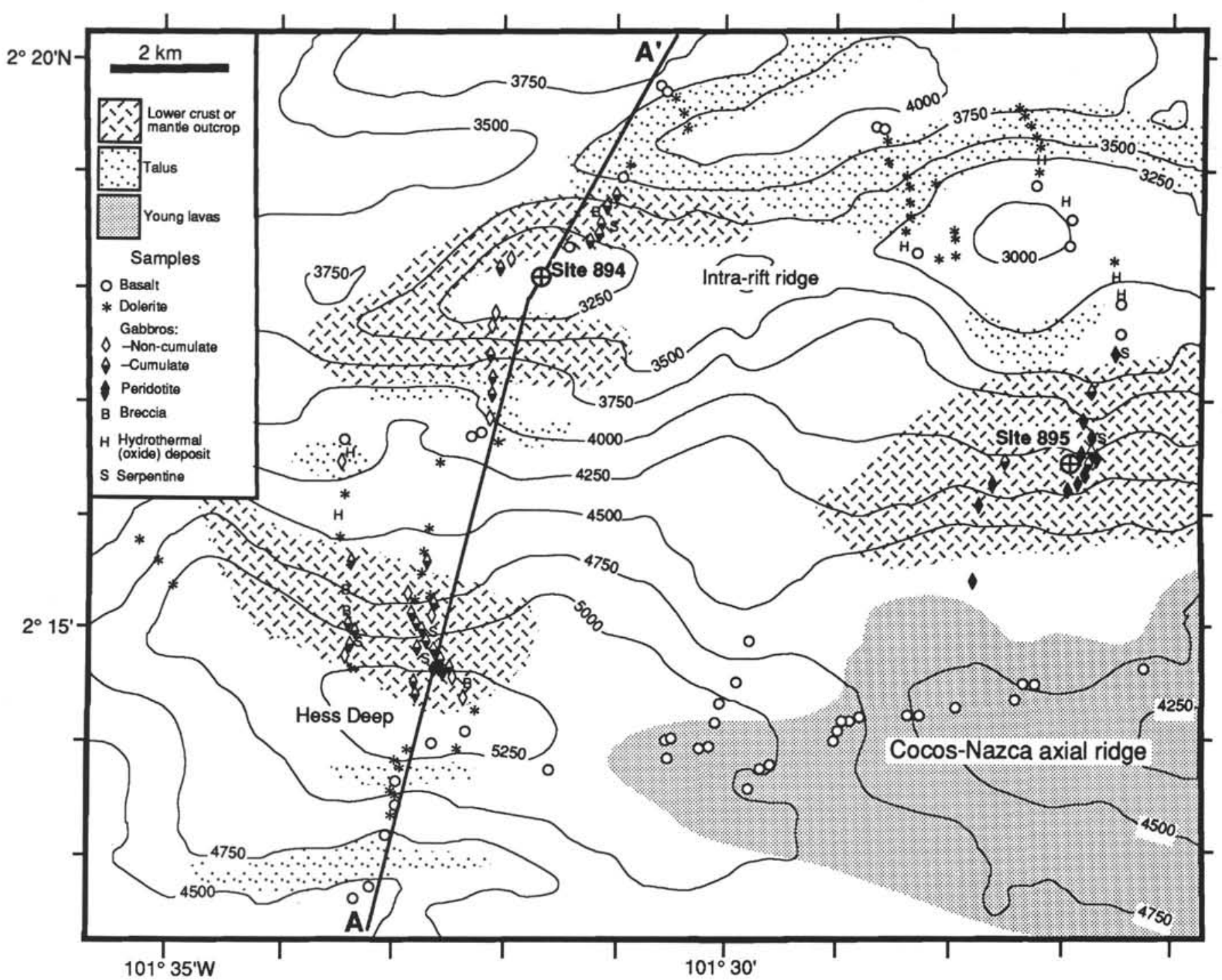

Figure 3. Bathymetry and disposition of outcrop in the vicinity of the intra-rift ridge, Hess Deep, as deduced from submersible and dredging operations (after Francheteau et al., 1990).

Table 1. Compilation of fault plane solutions near the Pacific-Cocos-Nazca triple junction.

\begin{tabular}{|c|c|c|c|c|c|c|c|c|c|c|c|c|}
\hline \multirow[b]{2}{*}{ Date } & \multirow[b]{2}{*}{ Time } & \multirow[b]{2}{*}{ Latitude } & \multirow[b]{2}{*}{ Longitude } & \multirow[b]{2}{*}{ Depth } & \multicolumn{3}{|c|}{ Nodal plane } & \multirow[b]{2}{*}{$\mathrm{S}_{v}$} & \multirow{2}{*}{$\begin{array}{c}\mathrm{S}_{H \max } \\
\text { azimuth }\end{array}$} & \multirow[b]{2}{*}{$\mathrm{S}_{h}$} & \multirow{2}{*}{$\begin{array}{c}\mathrm{S}_{h} \\
\text { plunge }\end{array}$} & \multirow[b]{2}{*}{ Reference } \\
\hline & & & & & Azimuth & Dip & Rake & & & & & \\
\hline 20-09-69 & & 1.78 & -101.03 & 33.0 & 024 & 60 & -105 & 1 & 031.6 & 2 & 13.0 & Forsyth, 1972 \\
\hline $21-01-70$ & $17: 51: 37.4$ & 7.03 & -104.24 & 33.0 & 332 & 41 & 106 & 3 & 050.7 & 1 & 5.0 & Bergman and Solomon, 1984 \\
\hline $02-05-72$ & $06: 56: 23.2$ & 5.22 & -100.32 & 10.0 & 332 & 49 & 280 & 1 & 144.9 & 3 & 3.5 & Bergman and Solomon, 1984 \\
\hline $11-09-75$ & $22: 00: 01.3$ & 7.05 & -104.18 & 10.0 & 307 & 44 & 093 & 3 & 034.9 & 1 & 1.0 & Bergman and Solomon, 1984 \\
\hline $29-10-75$ & $05: 01: 38.7$ & 3.92 & -103.61 & 33.0 & 220 & 66 & 260 & 1 & 044.1 & 2 & 9.1 & Wiens and Stein, 1984 \\
\hline $05-03-78$ & $12: 34: 09.9$ & 2.72 & -95.41 & 33.0 & 055 & 41 & -134 & 1 & 085.1 & 3 & 11.5 & Dziewonski et al., 1987a \\
\hline $18-07-78$ & $01: 41: 51.6$ & 2.22 & -97.95 & 33.0 & 291 & 45 & -090 & i & 111.0 & 3 & 0.0 & Dziewonski et al., 1987a \\
\hline $24-10-79$ & $16: 35: 31.8$ & 1.44 & -101.26 & 10.0 & 237 & 31 & -089 & 1 & 056.1 & 2 & 0.5 & Dziewonski et al., 1987b \\
\hline $11-05-85$ & $12: 44: 59.5$ & 1.93 & -101.13 & 10.0 & 125 & 62 & 003 & 2 & 082.7 & 1 & 17.4 & Dziewonski et al., 1986 \\
\hline $27-02-87$ & $01: 39: 55.6$ & 2.48 & -98.49 & 33.0 & 211 & 68 & -168 & 2 & 075.2 & 3 & 7.4 & Dziewonski et al., 1988 \\
\hline $12-02-88$ & $12: 10: 23.1$ & 2.12 & -99.03 & 10.0 & 207 & 79 & 180 & 2 & 072.5 & 3 & 7.8 & Dziewonski et al., 1989 \\
\hline $17-02-89$ & $00: 39: 11.4$ & 2.23 & -95.11 & 10.0 & 036 & 43 & -119 & i & 056.1 & 3 & 5.5 & Dziewonski et al., 1990a \\
\hline $16-07-89$ & $09: 37: 37.1$ & 2.58 & -101.32 & 10.0 & 253 & 90 & 180 & 2 & 118.0 & 1 & 0.0 & Dziewonski et al., 1990b \\
\hline $13-12-89$ & $13: 30: 32.6$ & 2.72 & -95.41 & 10.0 & 202 & 90 & -180 & 2 & 067.0 & 3 & 0.0 & Dziewonski et al., 1990c \\
\hline
\end{tabular}

Note: $\mathrm{S}_{v}$ is the index of that of the principal stress direction $\mathrm{S}_{1}, \mathrm{~S}_{2}, \mathrm{~S}_{3}$ that is closest to vertical; $\mathrm{S}_{h}$ is the index of that of the principal stress direction $\mathrm{S}_{1}, \mathrm{~S}_{2}, \mathrm{~S}_{3}$ that is closest to horizontal; $S_{h}$-plunge is the plunge of the principal stress direction $S_{1}, S_{2}, S_{3}$ that is closest to horizontal. 


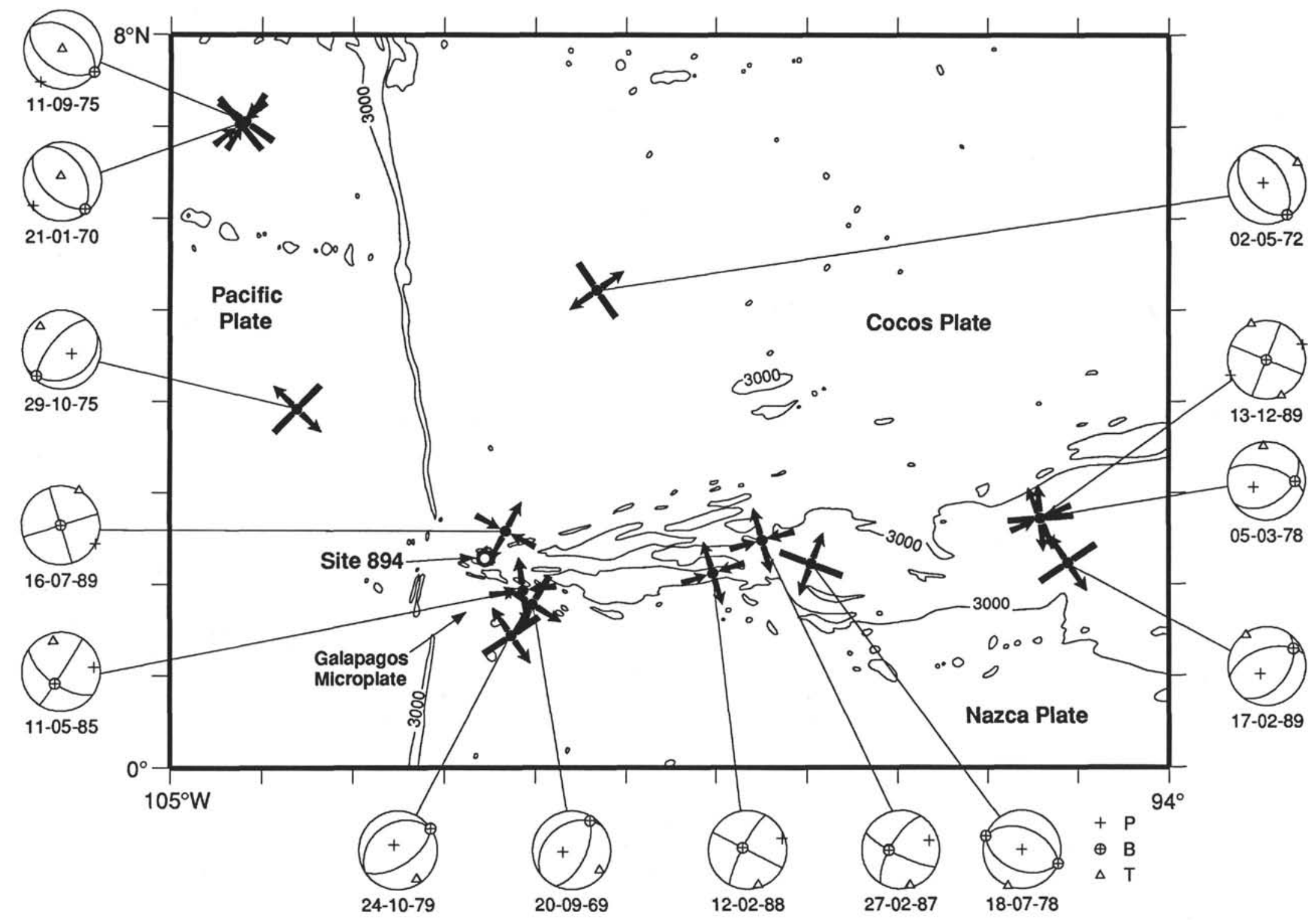

Figure 4. Cocos-Nazca-Pacific triple junction regional map (Mercator projection with Clarke's 1866 ellipsoid). Bathymetry contours at $3000 \mathrm{~m}$ are from Mammerickx and Smith (1994). Horizontal principal stress directions are inferred from the focal mechanisms given in Table 1 (maximum principal stress direction $=\mathrm{S}_{1}$; intermediate principal stress direction $=\mathrm{S}_{2}$, and minimum principal stress direction $=\mathrm{S}_{3}$, corresponding to inward-pointing arrows, bar, and outward-pointing arrows, respectively). The nodal planes are shown together with the P, B, and T axes. 


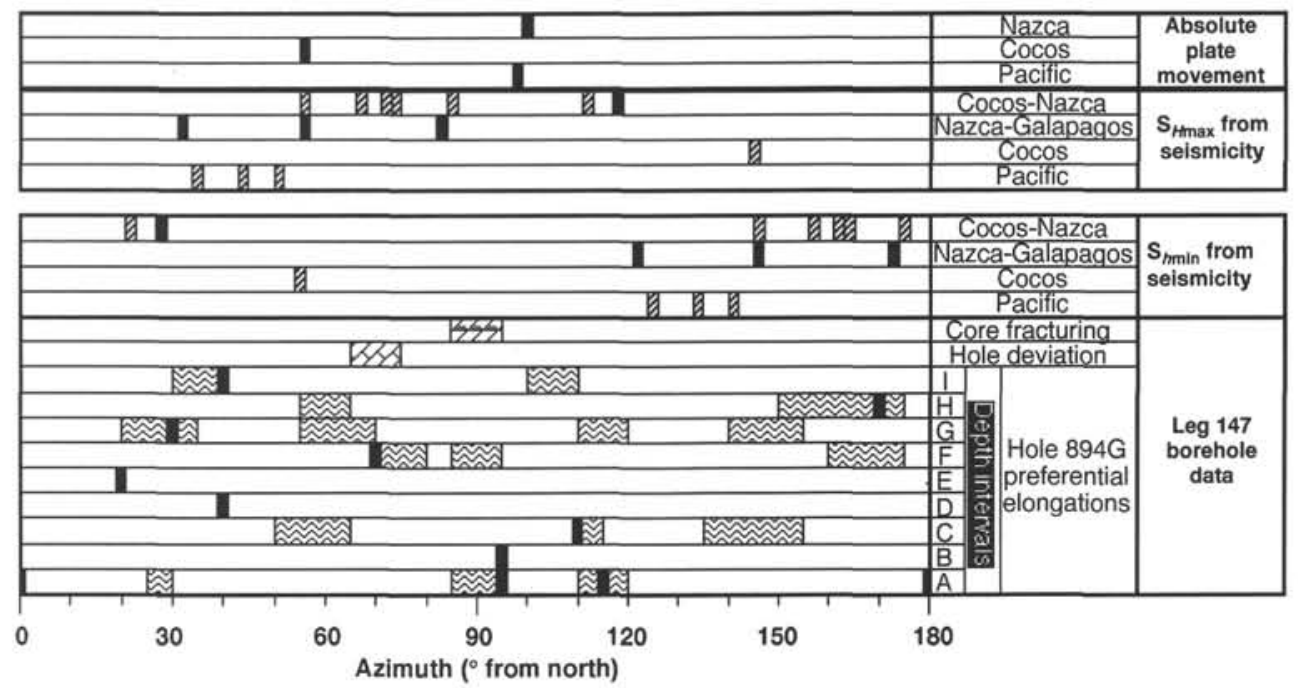

Figure 5. Correlation of present-day azimuthal stress direction indicators (modulo $180^{\circ}$ ). The azimuths of the minimum horizontal principal stress directions are sorted into four groups, corresponding to the two plate boundaries and the two tectonic plates for which intraplate events have been detected (inferred from the seismic events listed in Table 1 and shown on Figure 4). The four symbols with the black shadings in the rows $\mathrm{S}_{H \max }$ from seismicity and $\mathrm{S}_{h \min }$ from seismicity correspond to the events closest to Hess Deep. The maximum principal horizontal stress directions are compared with the absolute plate movement directions from Hey et al. (1977) and Hey (1977).The minimum principal horizontal stress directions are compared with the borehole elongation data from Hole 894G. The borehole data are subdivided into nine depth intervals, labeled A to 1, corresponding to those defined in Table 4 of Célérier et al. (this volume). For each depth interval, the narrow dark zone corresponds to the azimuth satisfying most breakout criteria in a single logging pass, whereas the wider lighter areas correspond to preferential enlargement direction deduced from all the logging passes together. The borehole deviation direction (modulo $180^{\circ}$ ) and the modal core fracture strike are also shown.

creases with increasing strain. Porphyroclasts include plagioclase (now completely altered), opaques, and amphibole, and also chlorite and prehnite. In a few instances, veins of chlorite-smectite were observed that had been sheared into the foliation. In turn, the cataclastic zones are cut by veins filled with chlorite/prehnite and zeolite/calcite, indicating that fluid infiltration continued after deformation. The presence of corrensite in the matrix of the cataclasites limits the maximum temperature of formation to less than $250^{\circ} \mathrm{C}$, and oxygen isotope data (Früh-Green, Plas, and Dell'Angelo, this volume) suggest temperatures continuing down as low as $150^{\circ} \mathrm{C}$.

\section{Veins and Fractures}

In marked contrast to the rarity of displacive deformation, brittle fracturing and fracture filling is extremely common in Site 894 cores. Manning and MacLeod (this volume) identify 1040 macroscopic veins in Hole $894 \mathrm{G}$ cores, at a density of 0.21 veins per meter. Virtually no nonmineralized fractures were observed. The mineralogies of vein fill in Hole $894 \mathrm{G}$ present a time-integrated record of the physico-chemical evolution of hydrothermal circulation in the upper part of the EPR (layer 3) plutonic section, documenting the cooling of the section from the moment of initial subsolidus penetration of seawater, through to its exhumation and exposure on the seafloor. Manning and MacLeod (this volume) recognize three principal mineralogical vein types in Hole 894G: amphibole veins, subdivided into microscopic and macroscopic types; chlorite veins, subdivided into chlorite-calc-silicate and chlorite-smectite subtypes; and zeolite-calcite veins.

\section{Microscopic Amphibole Veins}

Microscopic amphibole veins are the oldest veins recognized, and are responsible for grain-scale alteration of the gabbros, accounting for $10 \%$ to $>50 \%$ of the modal mineralogy. They take the form of an interconnected network of tiny (average $17 \mu \mathrm{m}$ wide) cracks filled by green, blue-green, and olive-green calcic amphibole, and occur pervasively throughout the Hole $894 \mathrm{G}$ section. Manning and MacLeod

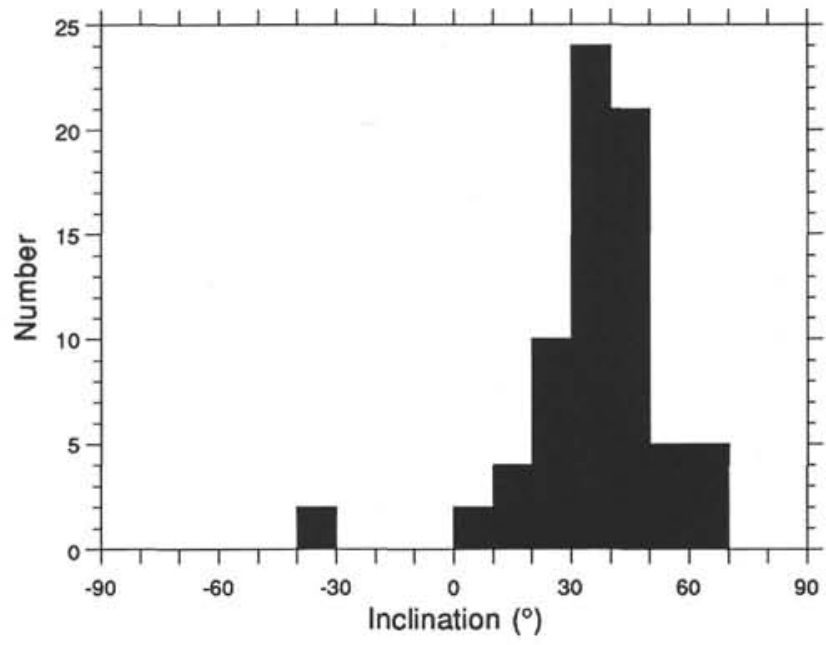

Figure 6. Histogram of inclinations of stable remanence directions, Hole 894G. $N=73$.

(this volume) show that more than $80 \%$ of grain boundaries were affected by the fluid flow at the time that this microfracture network was formed. They find that amphibole composition varies with the primary mineralogy of the vein wall, suggesting that material transport distances were short, and consistent with rapid reaction rates and low fluid fluxes. Presence of secondary clinopyroxene in association with the microscopic amphibole veins implies extremely high temperatures of metamorphism: Manning and MacLeod (this volume) calculate temperatures as high as $750^{\circ} \mathrm{C}$, with most mineral compositions implying amphibolite facies temperatures of $600^{\circ}-750^{\circ} \mathrm{C}$.

\section{Macroscopic Amphibole Veins}

Macroscopic amphibole-filled veins cross-cut their microscopic precursors in all cases. They are light green to blue in color, usually 
$<1 \mathrm{~mm}$ wide, and range from wispy, discontinuous features to straight-walled veins continuous for several centimeters. In hand specimen they are rare (only 44 were identified in total), and frequently difficult to identify, especially in the most strongly altered hosts. Mineral assemblages in the macroscopic veins are calcic, but differ from the microscopic vein amphiboles by having a compositional gap (between $\mathrm{Al}$-rich and $\mathrm{Al}$-poor types) that implies formation temperatures in the range $450^{\circ}-600^{\circ} \mathrm{C}$ (i.e., lower amphibolite facies to amphibolite-greenschist facies transition: Manning and MacLeod, this volume).

\section{Chlorite-Calc-silicate and Chlorite-Smectite Veins}

Chlorite-bearing veins are by far the most common in Hole 894G, with 987 veins recorded (Manning and MacLeod, this volume). These veins are characterized by chlorite-lined vein walls and usually by vein centers filled either with calc-silicates (epidote and prehnite) or smectite. A distinction between the mineralogies of vein center-fill was made during description of the cores, but this is largely arbitrary: a continuum of compositions is recognized, with some veins containing calc-silicates and also clay minerals as a late-infilling phase. Chlorite-calc-silicate veins are, however, predominantly (though not exclusively) older than the chlorite-smectite veins. Chlorite veins of both types cut the amphibole veins where cross-cutting relationships are preserved. Brecciated wall-rock clasts and evidence for multiple generations of infill attest to repeated opening and filling, locally under high pore-fluid pressures.

Chlorite veins are characteristically continuous, straight-sided, planar features up to $3 \mathrm{~mm}$ in width, and are often associated with alteration halos of white albitized plagioclase. They often form parallel sets of closely spaced veins cutting across the cores. Chlorite-calcsilicate veins $(N=404)$ are dark green to black in hand specimen, often with white prehnite centers. Chlorite-smectite veins $(N=583)$ are characterized by soft green, yellow or brown smectites in vein centers. The core is often broken along these planes of weakness. Late zeolites and calcite commonly fill residual pore space.

Temperature estimates for the formation of the chlorite-calc-silicate vein assemblage (Früh-Green, Plas, and Dell'Angelo, this volume) range as high as approximately $400^{\circ}-450^{\circ} \mathrm{C}$. Estimates of $300^{\circ}-400^{\circ} \mathrm{C}$ are consistent with the assemblage chlorite + albite + actinolite in the alteration haloes. Veining and alteration must have continued down to $150^{\circ}-250^{\circ} \mathrm{C}$, as determined from the compositions of clay mineralogies and oxygen isotope data from secondary plagioclase and calcite vein samples.

\section{Zeolite-calcite Veins}

White veins filled by zeolite and calcite are the youngest hydrothermal veins observed in Hole $894 \mathrm{G}$. They tend to have either zeolite or calcite fill, but rarely both. Neither are common $(N=5)$. The veins are similar in width to the other macroscopic types. Little wallrock alteration is associated with these veins, implying that waterrock reaction was limited. Temperature estimates for this latest phase of veining are as low as $150^{\circ} \mathrm{C}$ (Früh-Green et al., this volume).

\section{Vein Orientations}

The orientations of hydrothermal veins provide valuable information as to the physical conditions leading to the creation of fracture permeability in the Site 894 section, and the tectonic evolution of the site from its formation at the EPR until its eventual exhumation in the Hess Deep rift valley. Random orientations may result from the effects of local stress regimes, as might be expected for the cooling and thermal contraction of an initially isotropic body. Systematic nonrandom orientations, however, would be expected to record fracture formation under the influence of a regionally significant stress field.

Of the 1040 macroscopic veins measured by Manning and MacLeod (this volume) in cores from Hole $894 \mathrm{G}, 601$ were in core pieces that could be oriented relative to the fiducial axis of the borehole and 303 were in pieces for which the stable magnetic remanence direction had also been determined (MacLeod, Manning, et al., this volume). Orienting core pieces relative to this magnetic direction provides a common reference frame for comparing features in the core, assuming that all acquired their magnetizations in the same field direction; it does not, however, necessarily provide any external constraint relative to the present-day geographical reference frame in the present case, because of the likelihood (from the anomalous stable inclination directions discussed above) of a tectonic rotation or rotations with vertical axis component at Site 894 .

Vein orientations, subdivided by mineralogy and oriented with respect to the stable magnetic remanence direction, are presented in Figure 7. The relatively small number of amphibole veins restored in this way $(N=7)$ means that their orientations are poorly constrained from a statistical standpoint, but the data we do have show no preferred orientation. The chlorite-bearing veins, in contrast, show a very marked preferred orientation $(N=291)$. Their strikes are predominantly oriented in a direction approximately $110^{\circ}$ clockwise from the magnetic declination direction, and they have a moderate south-southwestward dip. The chlorite-calc-silicate vein orientations are slightly more clustered than the chlorite-smectite veins. The few reoriented zeolite-calcite veins $(N=5)$ have similar strikes to the chlorite veins, as do the few cataclastic shear zones for which orientation data are available.

\section{Downhole Logging}

Operational difficulties and very poor hole conditions in all Leg 147 boreholes conspired to restrict downhole logging operations in Hess Deep to a short interval of Hole 894G (between 45 mbsf and 80 mbsf; Célérier et al., this volume). The Formation MicroScanner (FMS) downhole imaging tool was deployed in an attempt to map the distribution and orientation of fractures on the borehole wall, and to relate the structural information thus obtained to the vein orientation data (oriented relative to the magnetic remanence direction). The FMS tool generates electrical images of portions of the borehole wall, mapping out small-scale variations in resistivity as detected by a series of electrodes mounted on pads that are pressed against the wall (Ekstrom et al., 1987). The tool carries a three-axis magnetometer, thus allowing dipping planar features to be oriented reliably to geographical coordinates. Because the earth's magnetic field typically contributes all but a few percent of the total field, directions determined by the downhole magnetometers are not normally affected significantly by rocks with moderate magnetic intensities (see Goldberg et al., 1992). The theoretical resolution of the FMS tool is approximately $0.5 \mathrm{~cm}$ although, in practice, considerably smaller features are discernible if the resistivity contrast is sufficiently large, as, for example, between a (low resistivity) water-filled fracture and a (high resistivity) lithified rock such as the gabbros encountered here.

The FMS data from Hole $894 \mathrm{G}$ are of very poor quality because of the extreme roughness and enlargement of the borehole. Nevertheless, MacLeod et al. (1995) and Célérier et al. (this volume) were successful in detecting a large number of low-resistivity, sub-planar to planar features on the FMS images. There is little doubt that these represent fractures, probably open and water-filled. In Figure 8, fractures are plotted as poles to planes in lower hemisphere, equal area stereographic projections, oriented relative to true north. These data yield a preferred pole to plane of $354.4^{\circ} ; 39.7^{\circ}(N=177)$, corresponding to a plane dipping at $50.3^{\circ}$ southwards, with strike of $084.4^{\circ}$ (Fig. 8 ). The marked preferred east-west strike is notable, being parallel to the trend of the Cocos-Nazca rift and of the intra-rift ridge at Site 894.

\section{Core-log Integration}

The veins measured in the core are predominantly planar (lined) fractures from the center of the borehole. The low-resistivity features identified on the FMS images are believed to be planar fractures on 

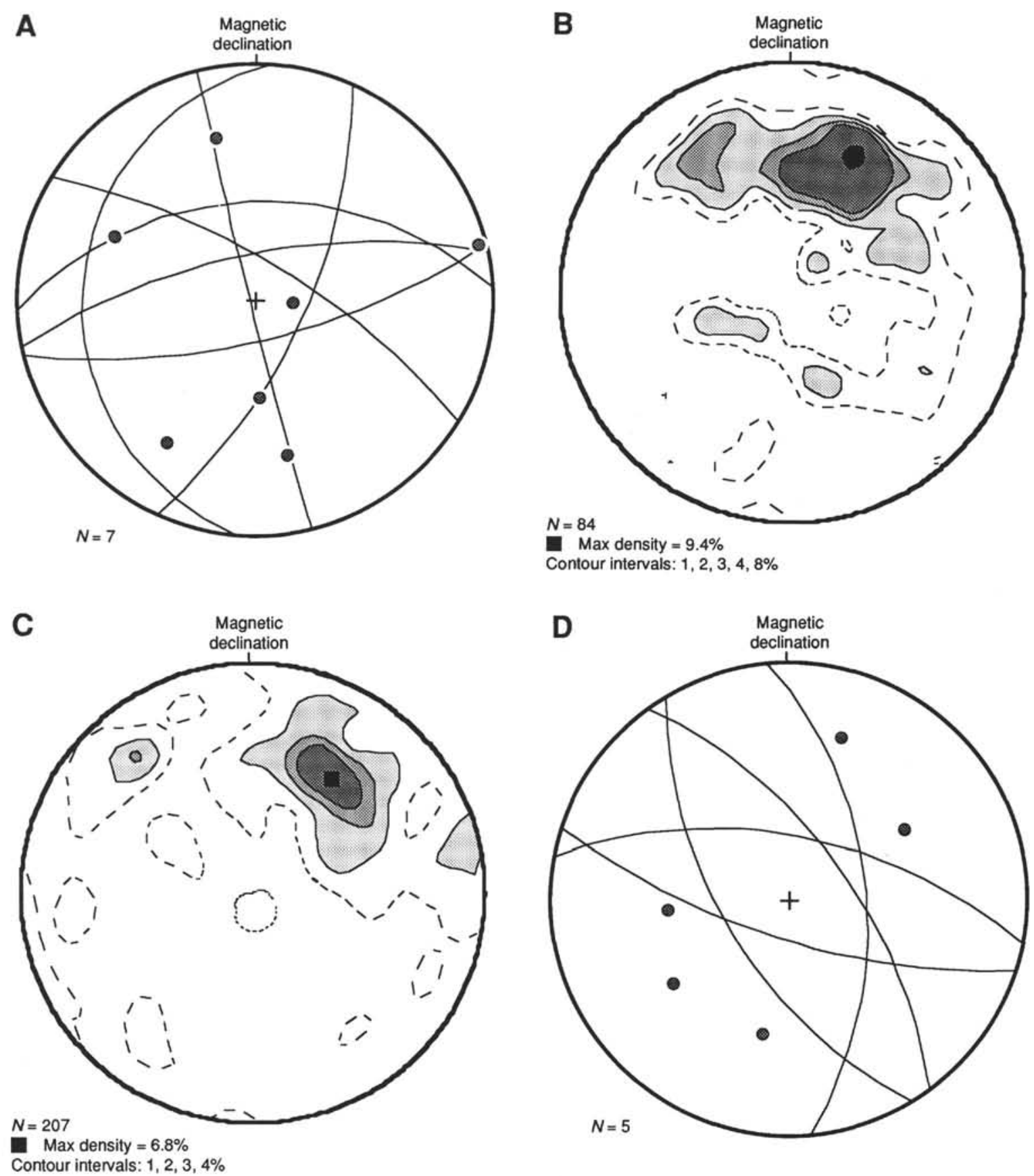

Figure 7. Orientations of hydrothermal veins relative to the stable magnetic declination direction, Hole $894 \mathrm{G}$, subdivided by mineralogy. A. Amphibole veins. B. Chlorite-calc-silicate veins. C. Chlorite-smectite veins. D. Zeolite-calcite veins. E. Orientations of all veins restored in both declination and inclination. Note that dips of planes are now subvertical. Equal area projection; poles to planes of veins plotted.

the borehole wall. Because of the poor quality of the FMS images, it is not possible to match the features on a 1:1 basis; however, the FMS fracture data considered together may be compared with the core fracture (vein) data from the same (45-80 mbsf) depth interval (MacLeod et al., 1995, Célérier et al., this volume). The distributions of fractures on both cores and logs are very similar: both show marked preferred orientations, with similar dips, and a maximum strike direction $\sim 15 \%$ of the total. There must be little doubt that the same features are being compared. The difference between the two is that whereas the FMS data are recorded relative to true north, the core data are measured relative to the stable magnetization direction, which was acquired when the gabbro section cooled, and which need not be north. Matching the two data sets (Fig. 9) implies that the stable magnetic remanence of the Hole $894 \mathrm{G}$ gabbros points toward the north-northwest. As discussed earlier, this cannot readily be explained in terms of secular variation, and is more readily explicable as a vertical-axis component of rotation either of $\sim 30^{\circ}$ counterclockwise (if normal polarity, i.e., declination points toward north) or $\sim 150^{\circ}$ clockwise (if the rocks are of reversed polarity). The former is obviously preferred in the absence of any other geological evidence for such large rotations, despite the previous inference of reversed polarity on the basis of its supposed $\sim 1$ Ma age (Gillis, Mével, Allan, 


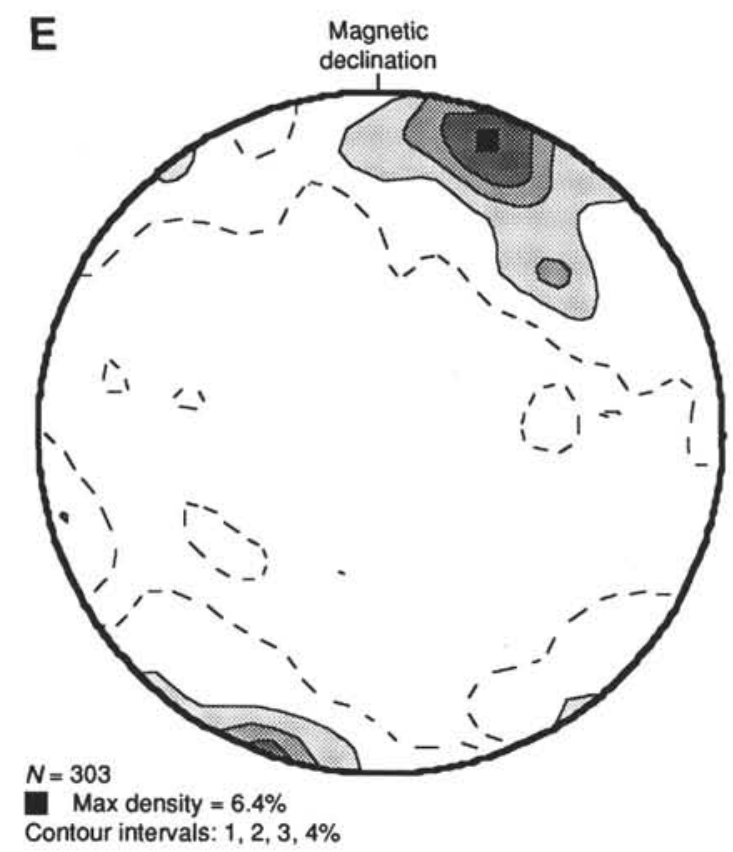

Figure 7 (continued).

et al., 1993). The core-log integration presented here, supported by the preliminary findings of Gee et al. (1992), strongly suggests that the Site 894 section is normally polarized, and hence acquired its magnetization either during the Brunhes Chron (i.e., $<0.73 \mathrm{Ma}$ ), or Jaramillo (0.91-0.98 Ma), Olduvai ( $\geq 1.6 \mathrm{Ma}$ ), or older subchrons.

\section{SITE 895}

\section{Lithostratigraphy}

Site 895 is located $9 \mathrm{~km}$ to the east of Site 894 , on the southern slopes of the intra-rift ridge, on a small north-trending spur leading up to the main part of the ridge (Gillis, Mével, Allan, et al., 1993). Six holes were drilled at three locations, at depths of between $3820 \mathrm{~m}$ and $3692 \mathrm{~m}$. Substantial penetration was made only at Holes 895C (37.9 $\mathrm{m}), 895 \mathrm{D}(93.7 \mathrm{~m})$, and $895 \mathrm{E}(87.6 \mathrm{~m})$. Serpentinized tectonite harzburgites and dunites were the most abundant rock type recovered, and were intercalated with troctolites, olivine gabbros, gabbros, and minor basaltic dikes. Proportions of these rock types varied from hole to hole, with harzburgites predominating in all holes except Hole $895 \mathrm{E}$. In this hole dunite was the most common rock type recovered, often associated with interstitial plagioclase and/or clinopyroxene. Progressive increase in the proportion of these interstitial phases leads to formation of troctolite and gabbro segregations in the cores; these are interpreted as melt impregnation/percolation channelways (Gillis, Mével, Allan, et al., 1993) located close to the crust-mantle transition zone. Early, high-temperature, pervasive ductile deformation fabrics are visible in harzburgites and dunites from Site 895. These are shown by Boudier et al. (this volume) to have been formed by flow under asthenospheric conditions beneath the EPR ridge axis.

\section{Rock Magnetism}

Inclinations of stable magnetic remanence directions from partially serpentinized harzburgites and dunites at Site 895 are deviated significantly away from the axial dipole inclination of $+4.6^{\circ}$ (Gillis, Mével, Allan, et al., 1993; Kelso et al., this volume; MacLeod, Manning, et al., this volume). As discussed earlier for Site 894, this is most readily interpreted in terms of a tectonic rotation or rotations of the samples subsequent to the acquisition of their primary remanences. Demagnetization characteristics of the peridotite samples indicate
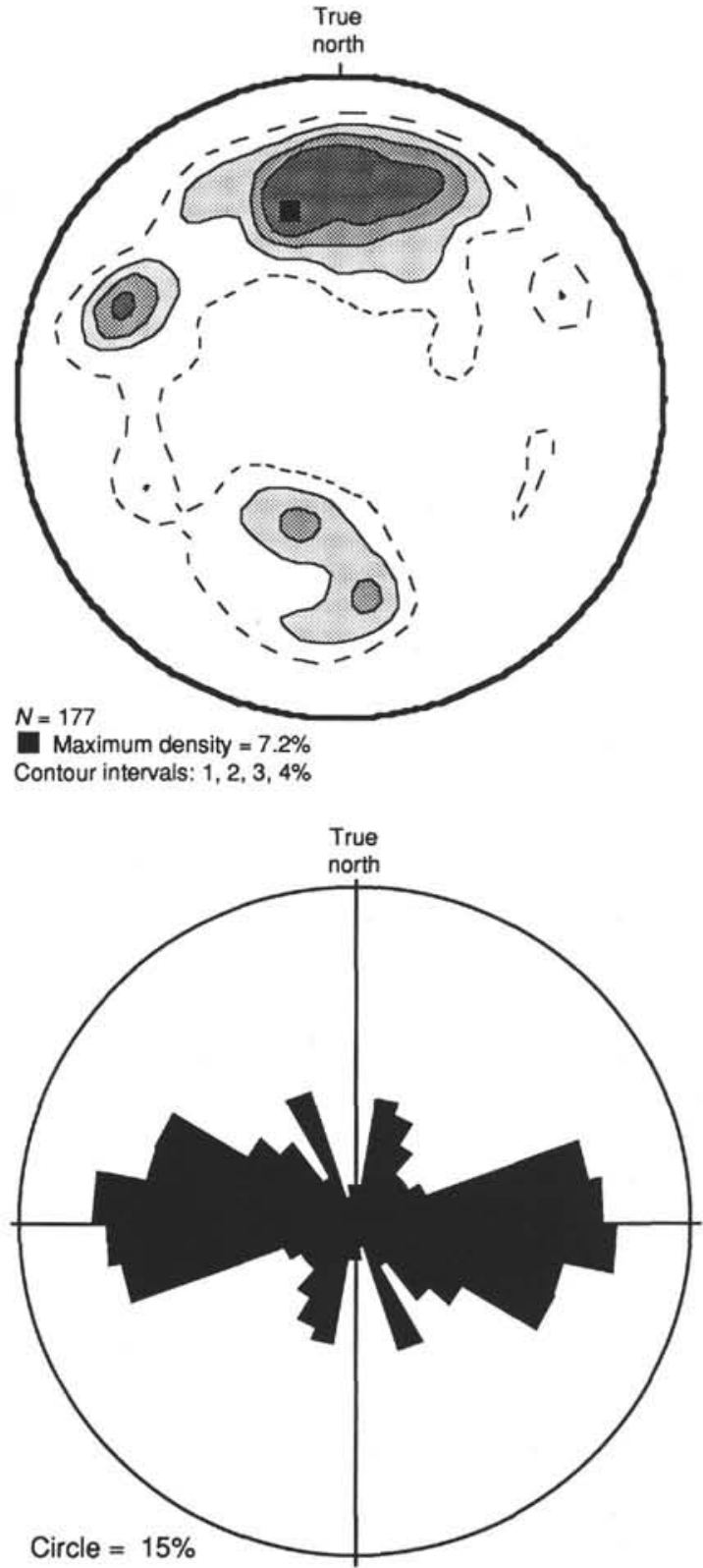

Figure 8. Orientations of fractures on the wall of Hole 894G, with respect to true north (FMS images, 45-80 mbsf).

that the magnetization is carried by magnetite, which was almost certainly formed during serpentinization. The median inclination for Site 895 is $36^{\circ}$ downward (Fig. 10), very similar to the mean inclination deduced from Site 894, and implying that Site 895 has also been subjected to a rotation with horizontal-axis component of this magnitude. No logging of Site 895 was possible, and therefore no external reference is available to constrain any vertical-axis component of rotation; nevertheless, the implication of the Site 895 magnetic inclinations is that the intra-rift ridge has been tilted northward (or rotated with a component of northward tilt) in a relatively coherent manner.

Mean inclinations from Holes 895B, 895C, and 895E are similar to the median inclination; the data from Hole $895 \mathrm{D}$, however, are widely dispersed, ranging from $-60^{\circ}$ to $+60^{\circ}$ (Kelso et al., this volume), thus biasing the mean for the site as a whole. This dispersion of inclinations may indicate that Hole 895D was drilled through a rubble pile (albeit one only slightly disrupted, because of the apparent coherence of the stratigraphy of the section); alternatively, noting the position of Hole 895D close to a break of slope at the foot of the intra- 


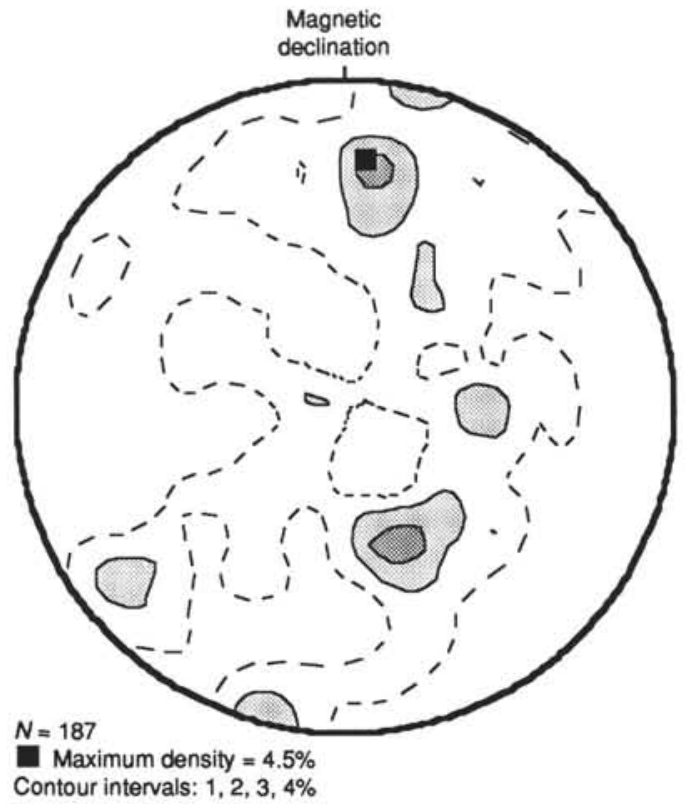

Figure 9. Comparison of the distributions of fractures and hydrothermal veins from the interval $45-80$ mbsf, Hole $894 \mathrm{G}$. This demonstrates that the magnetic declination direction of core samples is not directed toward north but north-northwest, compatible with a vertical-axis component of rotation of the section counterclockwise by approximately $30^{\circ}$.

rift ridge and very close to a broad, bright-backscattering lineament on GLORIA sidescan imagery (Searle and Francheteau, 1986), block disruption may have been caused by the proximity of the hole to the active normal fault zone that forms the southern margin of the intrarift ridge. The hole would therefore be located in the "process zone" of near-random disruption that often characterizes large natural fault zones (Agar, 1994). The extent to which vertical movement by faulting, rather than primary lateral heterogeneity in shallow mantle composition (cf. inferences made by Dick and Natland, this volume), is responsible for the marked difference in the stratigraphies of Holes $895 \mathrm{D}$ and $895 \mathrm{E}$, should not, therefore, be underestimated.

\section{Veins, Fractures, and Serpentinization}

The shallow mantle sequences at Site 895 record multiple stages of fluid infiltration, brittle fracturing, and veining under greenschist to zeolite facies conditions (Früh-Green, Plas, and Lécuyer, this volume; Mével and Stamoudi, 1994, and this volume). Metamorphism is dominated by hydration reactions and static replacement, resulting in mineral pseudomorphs and coronitic textures. As in the Site 894 gabbro section, displacive deformation is rare and tends to be concentrated in local, 1-5-cm-wide, penetrative shear zones in the gabbroic rocks (Früh-Green, Plas, and Lécuyer, this volume). Brittle fracturing and fracture filling is observed throughout the Site 895 core, with a larger density of discrete veins occurring in the ultramafic lithologies.

The harzburgites and dunites at Site 895 are extensively serpentinized $(50 \%-100 \%)$. Microscopically, these rocks are relatively undeformed and have typical pseudomorphic mesh-textures after olivine, indicating that the serpentinization process was essentially static. They are cut by multiple generations of fracture-filling veins. Lizardite and chrysotile are the dominate vein-filling minerals, with lesser amounts of chlorite, antigorite, magnetite, brucite, tremolite, talc, zeolite, and clay in varying proportions (Gillis, Mével, Allan, et al., 1993). Discrete fractures and microfractures filled with aragonite, commonly associated with incipient brecciation of the serpentinized

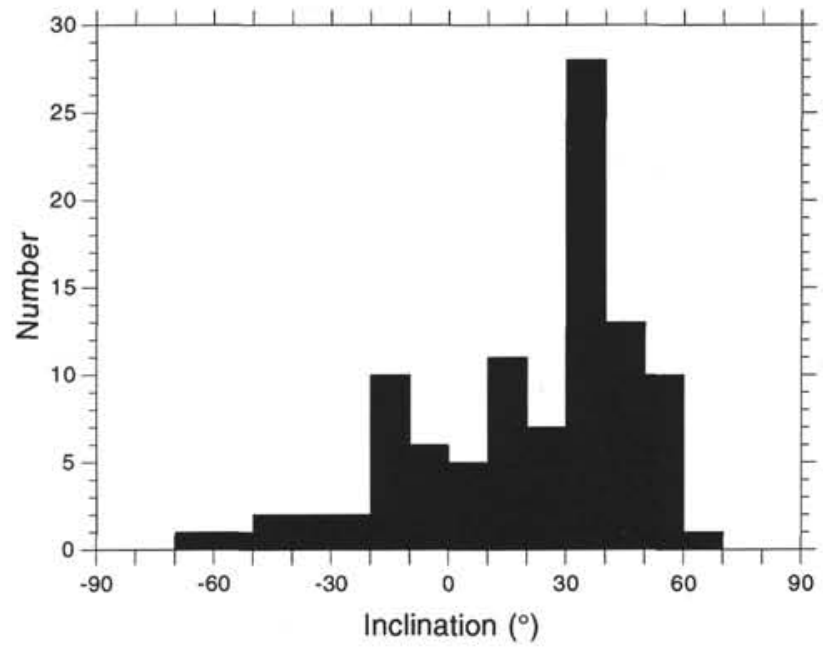

Figure 10. Histogram of inclinations of stable magnetic remanence directions from Site $895 . N=99$.

wall rock and an abundance of tremolite, represent the latest veining event. Vein morphologies vary from broad, planar, and continuous to thin, irregular, and discontinuous. Crack seal textures, indicative of multiple episodes of opening and mineralization, are often observed. In contrast to Site 894, no consistent relationships between vein mineralogy, morphology, relative age, and orientation (see below) were observed. On the basis of stable isotope data on bulk serpentine separates, vein serpentines, and serpentine-magnetite mineral pairs, Früh-Green, Plas, and Lécuyer (this volume) suggest that the main phase of serpentinization was related to veining and occurred at the relatively high temperatures of $400^{\circ} \pm 50^{\circ} \mathrm{C}$. They argue that in addition to seawater, magmatic volatiles associated with late magmatic activity and possibly $\mathrm{H}_{2}$ and $\mathrm{CH}_{4}$ released during serpentinization were significant components of the hydrothermal fluids. Oxygen isotope ratios of aragonite indicate the latest stage of veining occurred at ambient temperatures in the presence of pure seawater.

In the troctolitic and gabbroic rocks within the peridotites, progressive, static alteration from greenschist to zeolite facies conditions is documented by presence of distinct coronas, pseudomorphic textures, and vein infill. The less altered samples contain olivine, diopside, anorthite, tremolite, chlorite, and prehnite. Incipient rodingitization is associated with an increase in the amounts of prehnite, hydrogrossular, zeolites (predominantly thomsonite), smectitic clays, mica, and $\mathrm{Al}$ and $\mathrm{Fe}$ hydroxides. The extent of alteration and distribution of lower temperature mineral assemblages is related to an increase in the density of mineral-filled microfractures and macroscopic veins (Früh-Green, Plas, and Lécuyer, this volume). Veins in the mafic lithologies vary from discontinuous, filled microfractures to discrete networks of veins up to $1 \mathrm{~cm}$ thick. Filled microfractures are most common and form sinuous, anastomosing networks with variable thickness, length, and mineralogies. Both monomineralic and composite, zoned veins and veinlets are observed. Vein fillings include diopside, chlorite, tremolite, calcic plagioclase, prehnite, talc, serpentine, magnetite, zeolite, clays, rare epidote and calcite. Multiple, cross-cutting fracture filling phases are common, with variable infill mineralogies depending on the host mineral that is cut. The mineral assemblages in the mafic rocks and veins are more diagnostic of alteration temperatures than those in the peridotites: Früh-Green, Plas, and Lécuyer (this volume) and Mével and Stamoudi (this volume) estimate temperatures initially as high as $450^{\circ}-600^{\circ} \mathrm{C}$, but that most alteration (and greatest flux of seawater) occurred when temperatures were in the approximate range $350^{\circ}-400^{\circ} \mathrm{C}$. These authors consider this main alteration "event" to be synchronous with the principal period of fracturing and chlorite vein formation at Site 894 . 


\section{Veins in cores} 45-80 mbsf
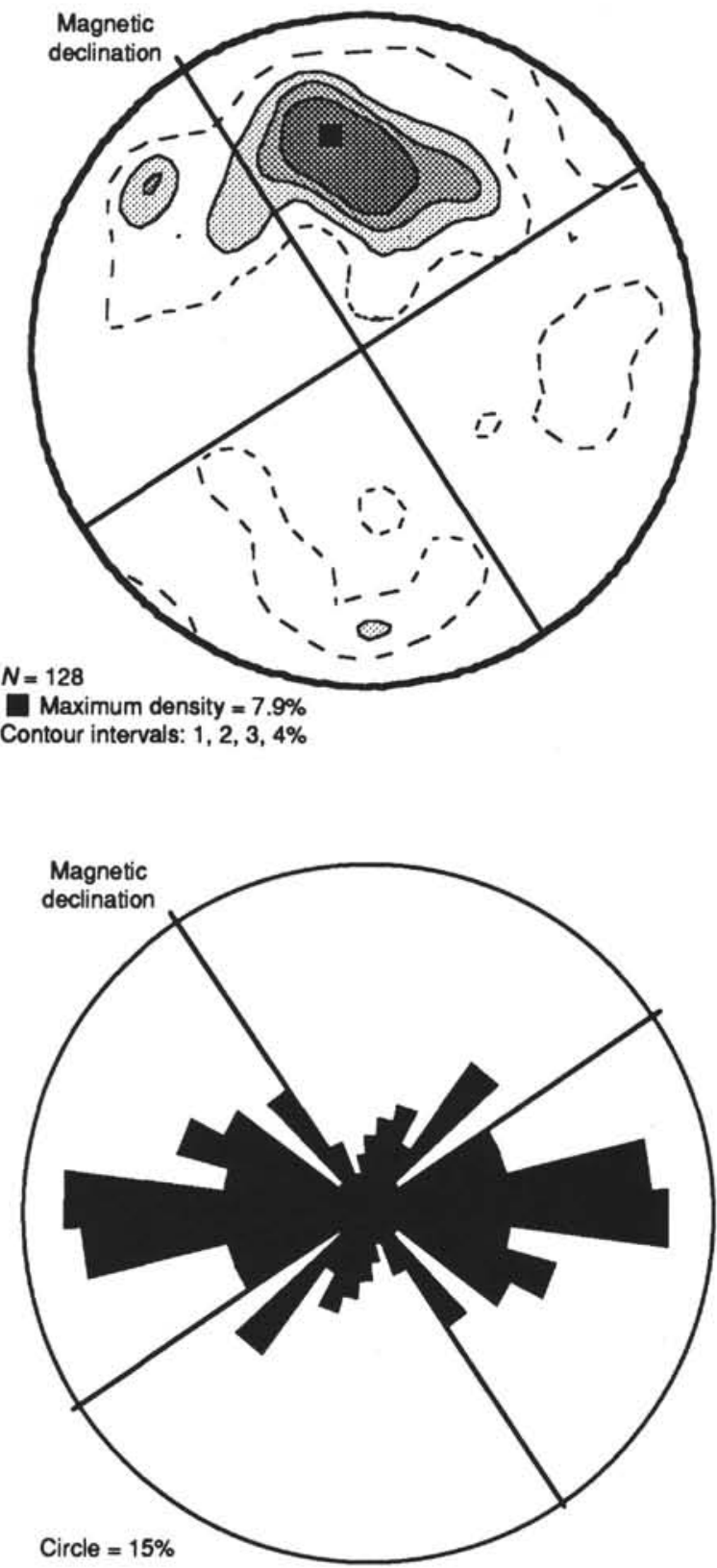

Fractures on

FMS images 45-80 mbsf
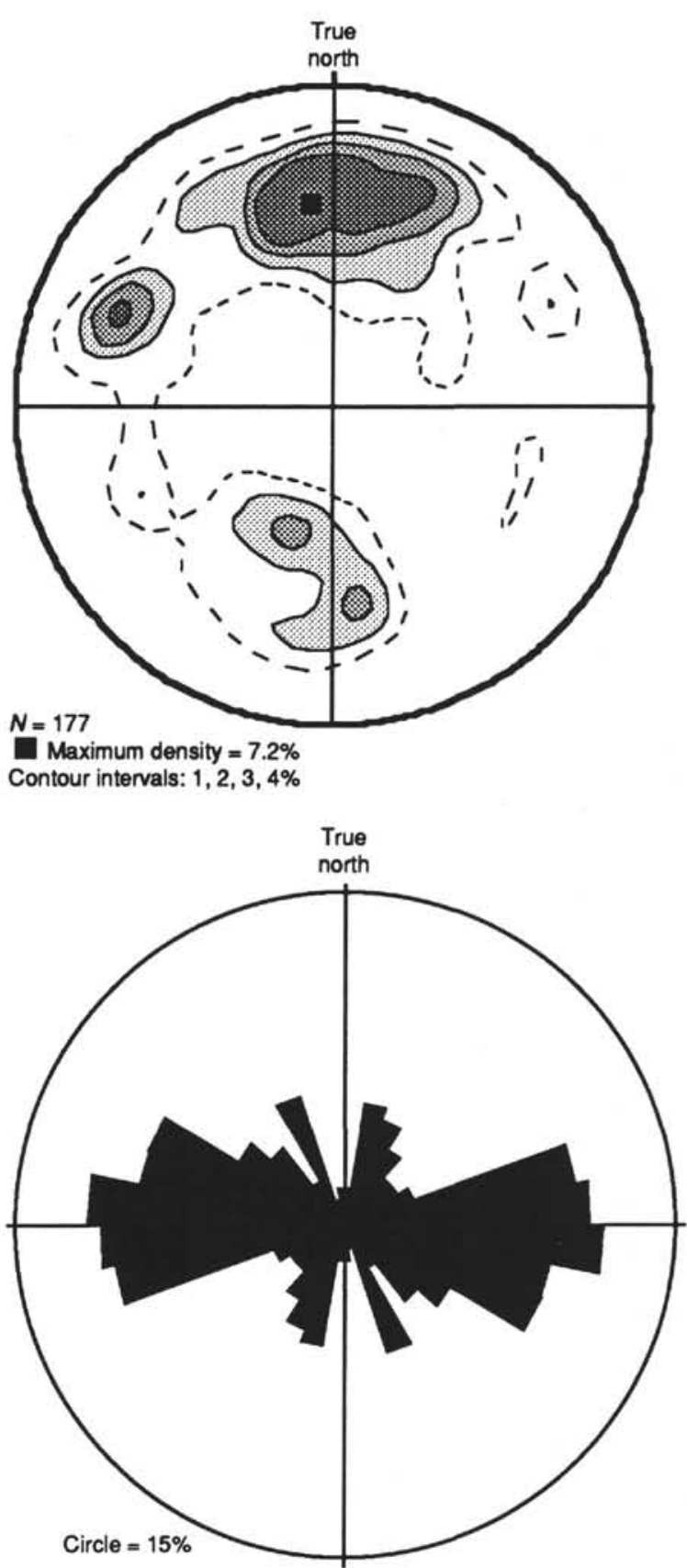

Figure 11. Contoured equal-area stereographic projection of poles to planes of serpentinite veins from Site 895, oriented with respect to the stable magnetic remanence direction, and assuming an inclination of $+4.6^{\circ}$.

\section{Vein Orientations}

Orientations of veins at Site 895 restored relative to the stable magnetic remanence direction and inclination $(N=187)$ are significantly more scattered than at Site 894 , with larger numbers of shallowly dipping veins and vein networks (Fig. 11; see also Gillis, Mével, Allan, et al., 1993). Note that data corrected only in declination are even more scattered because of the near-random inclinations of samples from Hole $895 \mathrm{D}$. A preference is observed among steeply dipping veins for a general west-northwest orientation relative to the magnetic declination direction. This is directly comparable with the Hole $894 \mathrm{G}$ veins restored in the same way. Although much of the veining at Site 895 is probably caused as a result of volume changes associated with serpentinization, the presence of a significant number 
of veins parallel to the dominant chlorite vein set in Hole 894G suggests that some role for far-field tectonic stresses in allowing initial water access is likely.

\section{DISCUSSION}

\section{Tectonic Evolution of Intra-rift Ridge}

\section{Exhumation of Mid-crustal Levels}

Leg 147 drilling verified the first-order hypothesis that the crustal section and underlying shallow mantle lithologies now exposed in Hess Deep were formed by seafloor spreading at the north-south trending EPR. This lithosphere was transported eastward away from the EPR ridge axis and became influenced by extensional tectonism caused by amagmatic rifting in advance of the westward-propagating Cocos-Nazca spreading center. The combined structural, borehole geophysical, paleomagnetic, petrological, and geochemical studies from Leg 147 operations summarized here contribute significantly to our understanding of the general processes by which the above occurred.

Seawater influx into layer 3 , the plutonic portion of the oceanic crust, commenced soon after crystallization, and while the host was at a very high temperature (estimated at up to $750^{\circ} \mathrm{C}$; Manning and MacLeod, this volume). Pervasive influx of water along randomly oriented microfracture networks and grain boundaries gave rise to significant mineralogical and isotopic alteration of the section, mostly at temperatures of $600^{\circ}-750^{\circ} \mathrm{C}$ (Manning and MacLeod, this volume; Lécuyer et al., this volume). This permeability was probably created by tensile brittle failure upon subsolidus cooling and thermal contraction of the gabbro as it was transported away from the ridge axis (e.g., Lister, 1974). Comparison with numerical simulations of heat flow and material transport (e.g., Phipps Morgan and Chen, 1993; Henstock et al., 1993) suggests that this early fracture permeability must have been established within several tens of thousands of years after axial magma emplacement and within a few kilometers of the ridge axis (here spreading at $65 \mathrm{~km} / \mathrm{yr}$ half rate) (Manning and MacLeod, this volume).

At the point at which the upper plutonic section had cooled to the upper greenschist facies (a temperature of approximately $450^{\circ} \mathrm{C}$ ) it became influenced for the first time by the effects of Cocos-Nazca rifting. Development of a dense array of east-west, steeply dipping, tensile (mode I) fractures occurred almost certainly in response to the north-south, far-field extensional stresses expected for Cocos-Nazca spreading. The moment at which this changeover occurred is less well constrained by theoretical studies than for the higher-temperature veining; however, it may be estimated at several to tens of kilometers away from the axis, and tens to a couple of hundred thousand years after axial magmatism. This is roughly comparable to the distance east of the present-day EPR axis that the first east-west lineaments are observed today (approximately $25 \mathrm{~km}$, from GLORIA sidescan sonar records: Searle and Francheteau, 1986).

The observation of lower-temperature phases in the centers of veins whose walls are lined by higher-temperature phases suggests that the east-west fractures were not sealed, but maintained their permeability, presumably upon continued extensional deformation. All subsequent fluid circulation and cooling of the section (documented down to approximately $150^{\circ} \mathrm{C}$ ) appears to have been controlled strongly by this permeable fracture network.

Cataclastic shear zones (east-west striking, moderately southward-dipping, and with normal senses of motion) are almost certainly related to the differential uplift of intra-rift ridge. Metamorphic temperatures in the range $150^{\circ} \mathrm{C}$ to no more than $250^{\circ} \mathrm{C}$ indicate that the cataclastic deformation occurred relatively late in the history of the EPR gabbros. Eckhardt and Puchelt (this volume) suggest a minimum unroofing age of $50 \mathrm{ka}$ for the inter-rift ridge, based upon the observed thickness of sediment and known sedimentation rates for the area. A recent microearthquake study of the Hess Deep area indicates that the intra-rift ridge is seismically very active (Porras et al., 1995).

\section{Exhumation of the Shallow Mantle}

The processes leading to exposure of the sub-EPR shallow mantle are not as well constrained as for mid-crustal levels. Nevertheless, Früh-Green, Plas, and Lécuyer (this volume) and Mével and Stamoudi (1994, and this volume) document minor amounts of early alteration at temperatures of $450^{\circ} \mathrm{C}$ to $600^{\circ} \mathrm{C}$, followed by larger scale influx of seawater down to Moho level and consequent widespread serpentinization, probably at $350^{\circ}-400^{\circ} \mathrm{C}$. This was almost certainly aided, if not caused, by a system of steep, east-west fractures associated with Cocos-Nazca rifting, probably at a similar time to that inferred above for the crustal section, and at a distance estimated at approximately $30 \mathrm{~km}$ from the EPR axis (Mével and Stamoudi, 1994). In the peridotites, further permeability was created by volume changes associated with serpentinization, which near-random process gives rise to a much greater variability in observed vein orientations.

Previous workers (Francheteau et al., 1990) hypothesized that serpentinite diapirism was responsible for uplift of the intra-rift ridge, and that serpentinized peridotite samples recovered by submersible from the vicinity of Site 895 were partly responsible. However, the preservation of pseudomorphic mesh textures in all serpentinized ultramafic lithologies observed during Leg 147 operations, and of a coherent mantle fabric overprinted by the serpentinization (Boudier et al., this volume), suggests that the serpentinization was a predominantly static phenomenon. Exhumation of the shallow mantle on the seafloor is therefore likely to have been by faulting of coherent blocks rather than incoherent diapirs. This is supported by velocity data from beneath the intra-rift ridge (Wiggins et al., 1993), which suggest that high velocities typical of mafic lower crustal rocks (and hence not serpentinite) underlie the ridge.

\section{Origin of Tectonic Rotations}

The anomalous directions of restored paleomagnetic data from the Leg 147 drillsites provide convincing evidence for the tectonic rotation of lower crustal and shallow mantle lithologies exposed on the intra-rift ridge within Hess Deep. Oriented samples of sheeted dikes from the northern and southern walls of Hess Deep, collected by Hurst et al. (1994) using the $A L V I N$ submersible, indicate that some rotation has also occurred at upper crustal levels elsewhere within the rift valley. These dike samples, too, show anomalously steep inclinations (mostly positive), and have declinations that lie predominantly within the southeastern quadrant.

The anomalous magnetic inclination data from the two ODP drill sites imply that the intra-rift ridge has been subjected to a horizontalaxis component of tectonic rotation of approximately $30^{\circ}-40^{\circ}$ toward the north, probably as a relatively coherent block. Comparison of core and downhole logs allows us to identify a $30^{\circ}$ counterclockwise vertical axis component of rotation at Site 894. It is not possible to determine unequivocally whether the vertical and horizontal components of rotation here identified are part of a single rotation inclined about an inclined axis, or whether they result from composite rotation episodes. It is not possible, either, to find a uniquely constrained rotation axis without other, external structural criteria. On purely geometrical grounds, assuming the minimum possible amount of rotation about a single axis that can account for the difference between the expected and observed directions of the magnetic vector, a rotation of approximately $45^{\circ}$ counterclockwise, about a moderately east-plunging axis, can be derived (Fig. 12). We doubt whether this axis has any geological significance; it certainly does not accord with the kinematic information from veins and cataclasites from Site 894 


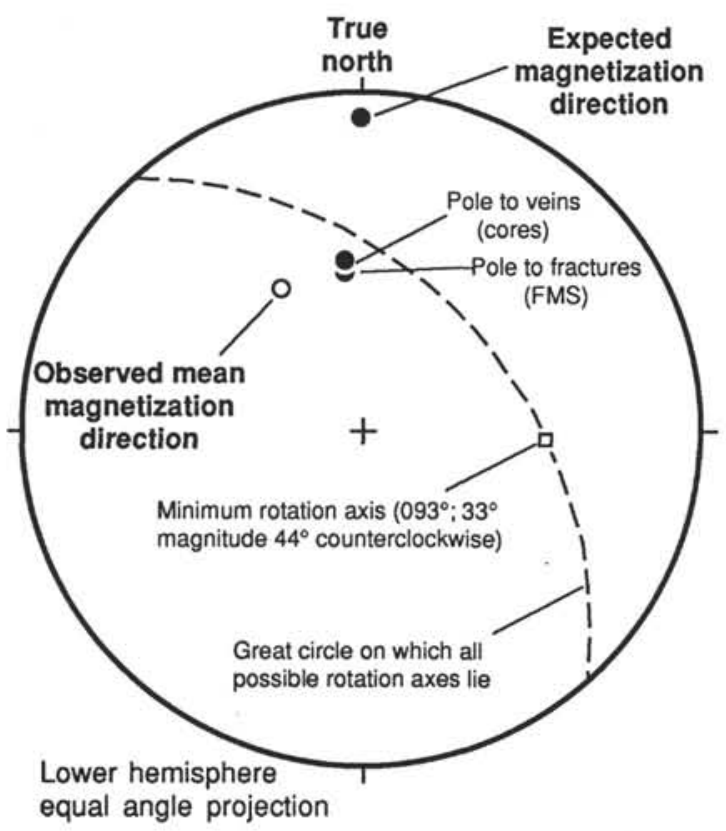

Figure 12. Equal-angle stereographic projection of angular relationships and possible axes of tectonic rotation. The axis or axes of rotation responsible for rotating the Hole $894 \mathrm{G}$ remanence directions from the expected dipole direction to their inferred present-day orientation are not uniquely constrained; however, if a single tectonic rotation is responsible, its axis must lie on the great circle outlined by the dashed line. The minimum rotation required to move the remanence direction from its original to its present position may be calculated as approximately $44^{\circ}$ clockwise about a moderately eastwardplunging axis (indicated by the white square). See text for discussion.

(for pure normal slip on east-west striking structures). To accommodate such a rotation a highly oblique slip direction would be imparted on planes with this orientation, and this is not observed.

If certain assumptions are made, however, some constraint can be placed on the tectonic processes that gave rise to the rotation or rotations. This constraint comes from a consideration of the timing of rotation. At Site 895, the peridotites must have acquired their remanences upon serpentinization (and consequent liberation of magnetite; Kelso et al., this volume); hence the tilting of the section (to give the mean $+40^{\circ}$ inclinations) must necessarily have post-dated the serpentinization (interpreted above as relating to the influx of water to Moho levels at the time of Cocos-Nazca rifting). The northward tilting or component of tilting of the intra-rift ridge may therefore be related to the predominantly extensional tectonics associated with Hess Deep rifting. A possible cross-section drawn across the intra-rift ridge, incorporating the tectonic tilting and not requiring serpentinite diapirism, is presented in Figure 13C. Northward rotation of the crustal and shallow mantle section occurred above a south-dipping low-angle detachment surface, as proposed by Francheteau et al. (1990, their model "B"; Fig. 13B); however, we instead propose that isolation and uplift of the intra-rift ridge was most likely to have been achieved by down-to-the-south displacement of the detachment by a later, high-angle normal fault, possibly aided by footwall uplift. In this scenario the high-angle normal fault (now forming the southern scarp of the intra-rift ridge) would have been initiated upon the continuation of Cocos-Nazca rifting after the detachment had become geometrically incapable of accommodating further strain (cf. Nur et al., 1986).

At Site 894 we know that the stable magnetic remanence was acquired shortly after cooling, and that the chlorite veins certainly postdated this. What we do not know for certain is the original orientation of the chlorite veins. If the assumption is made that the chlorite vein set was formed with an east-west strike (i.e., the same as observed at the present day from the FMS data), which is reasonable in the context of Cocos-Nazca-Hess Deep rifting, then the vertical axis component of rotation must have predated chlorite vein formation: the difference in azimuth between the vein strikes and the magnetic declination direction is $\sim 60^{\circ}$, and this should not change during rotation.

Taking the above arguments to their logical conclusion, we are left with the premise that a $\sim 30^{\circ}$ counterclockwise vertical axis rotation occurred at a very early stage (within a few kilometers to tens of kilometers of the ridge axis; see above), prior to formation of the chlorite vein set (which records temperatures of up to $450^{\circ} \mathrm{C}$ ). This was followed by a later (post-serpentinization) northward tilting of the whole intra-rift ridge by $30^{\circ}-40^{\circ}$ (when the mantle section was cooler than $350^{\circ}-400^{\circ} \mathrm{C}$ ). While this model might appear to be contrived, there is some geological evidence in its favor. As outlined above, the cataclasites and mode I veins imply pure normal extension across the Cocos-Nazca-Hess Deep rift, rather than the oblique extension required if both vertical and horizontal components were to be accommodated about a single, inclined axis such as that calculated above (see Fig. 12). Furthermore, substantial areas of north-northwest-oriented abyssal hill fabrics may be identified on multibeam bathymetry and GLORIA data in the overlap basin between the "duelling" overlapping spreading centers at the present-day EPR due west of Hess Deep and, moreover, in several relict areas of northnorthwest striking abyssal hill lineations stranded within Hess Deep itself (Fig. 2). These north-northwest-trending areas have been interpreted by Lonsdale $(1988,1989)$ as remnants of originally northsouth EPR seafloor that were rotated counterclockwise by the wellknown process of lithospheric transfer in the overlap basin between the duelling, right-stepping overlapping spreading centers/propagating rifts on the EPR at $2^{\circ} \mathrm{N}$, directly west of Hess Deep.

We tentatively conclude that a two-stage model is appropriate to explain the anomalous magnetization directions identified from the restored Leg 147 paleomagnetic data. A very early counterclockwise rotation of approximately $30^{\circ}$ about a steeply plunging axis is thought to have taken place as a result of spreading-related complexities at the EPR axis. At a later stage, when the lithosphere now exposed on the intra-rift ridge had been transported eastward some tens of kilometers into the Hess Deep rift, it was tilted toward the north, probably above a south-dipping detachment fault. Uplift, exposure of the lower crust and shallow mantle and isolation of the horst block within the rift valley was probably effected by post-detachment normal faulting. Serpentinite diapirism need not have played a significant role.

With the complex geometry of rifting in Hess Deep it is improbable that the model proposed here for the intra-rift ridge can be applied directly to the sheeted dikes sampled by Karson et al. (1992) and Hurst et al. (1994) from the north and south walls of Hess Deep; however, given this complexity, it is equally likely that the dikes may also have suffered compound rotations, and a similar history of early vertical-axis rotation close to the EPR followed by later deformation associated with Hess Deep rifting could provide an alternative equally viable to the models discussed by Hurst et al. (1994).

\section{ACKNOWLEDGMENTS}

We are most grateful to Paul Kelso, Janet Pariso, and Carl Richter for generously making their post-cruise magnetic measurements available to us. We would also like to thank Françoise Boudier and Lori Kennedy for help in acquiring the structural data on board ship, John Madsen and Jeff Fox for constructive reviews of the manuscript, and Roger Searle for allowing us access to the original Galapagos GLORIA data. CJM would like to acknowledge financial support from the Natural Environment Research Council. 


\section{REFERENCES}

Agar, S.M., 1994. Rheological evolution of the ocean crust: a microstructural view. J. Geophys. Res., 99:3175-3200.

Anderson, E.M., 1905. The dynamics of faulting. Trans. Edinburgh Geol. Soc., 8:387-402.

Angelier, J., 1984. Tectonic analysis of fault slip data sets. J. Geophys. Res., 89:5835-5848.

Bergman, E.A., and Solomon, S.C., 1984. Source mechanisms of earthquakes near mid-ocean ridges from body waveform inversion: implications for the early evolution of oceanic lithosphere. J. Geophys. Res. 89:11415-11441.

Cannat, M., Karson, J.A., Miller, D.J., et al., 1995. Proc. ODP, Init. Repts. 153: College Station, TX (Ocean Drilling Program).

Célérier, B., 1988. How much does slip on reactivated fault plane constrain the stress tensor? Tectonics, 7:1257-1278.

Dick, H.J.B., and Natland, J.H., 1994. Melt transport beneath fast and slow spreading ridges. Eos, 75:626.

Dick, H.J.B., Schouten, H., Meyer, P.S., Gallo, D.G., Bergh, H., Tyce, R., Patriat, P., Johnson, K.T.M., Snow, J., and Fisher, A., 1991. Tectonic evolution of the Atlantis II Fracture Zone. In Von Herzen, R.P., Robinson, P.T., et al., Proc. ODP, Sci. Results, 118: College Station, TX (Ocean Drilling Program), 359-398.

Dziewonski, A.M., Ekström, G., Franzen, J.E., and Woodhouse, J.H., 1987a. Global seismicity of 1978: centroid-moment tensor solutions for 512 earthquakes. Phys. Earth Planet. Inter., 46:316-342.

_ 1987b. Global seismicity of 1979: centroid-moment tensor solutions for 524 earthquakes. Phys. Earth Planet. Inter., 48:18-46.

- 1988. Centroid-moment tensor solutions for January-March 1987. Phys. Earth Planet. Inter., 50:116-126.

_, 1989. Centroid-moment tensor solutions for January-March 1988. Phys. Earth Planet. Inter., 54:22-32.

_ 1990 a. Centroid-moment tensor solutions for January-March 1989. Phys. Earth Planet. Inter., 59:233-242.

Dziewonski, A.M., Ekström, G., Woodhouse, J.H., and Zwart, G., 1990b. Centroid-moment tensor solutions for July-September 1989. Phys. Earth Planet. Inter., 62:185-193.

_ 1990c. Centroid-moment tensor solutions for October-December 1989. Phys. Earth Planet. Inter., 62:194-207.

Dziewonski, A.M., Franzen, J.E., and Woodhouse, J.H., 1986. Centroid-moment tensor solutions for April-June 1985. Phys. Earth Planet. Inter., $41: 215-224$.

Ekstrom, M.P., Dahan, C., Chen, M.-Y., Lloyd, P., and Rossi, D.J., 1987. Formation imaging with microelectrical scanning arrays. Log Analyst, 28:294-306.

Forsyth, D.W., 1972. Mechanisms of earthquakes and plate motions in the east Pacific. Earth Planet. Sci. Lett., 17:189-193.

Francheteau, J., Armijo, R., Cheminée, J.L., Hekinian, R., Lonsdale, P.F., and Blum, N., 1990. 1 Ma East Pacific Rise oceanic crust and uppermost mantle exposed by rifting in Hess Deep (equatorial Pacific Ocean). Earth Planet. Sci. Lett., 101:281-295.

_ 1992. Dyke complex of the East Pacific Rise exposed in the walls of Hess Deep and the structure of the upper oceanic crust. Earth Planet. Sci. Lett., 111:109-121.

Gee, J., Natland, J.H., Hurst, S.D., and Nilsson, K., 1992. Magnetic properties of ocean crust samples from Hess Deep: implications for marine magnetic anomalies. Eos, 73:490.

Gillis, K., Mével, C., Allan, J., et al., 1993. Proc. ODP, Init. Repts., 147 College Station, TX (Ocean Drilling Program).

Goldberg, D., Broglia, C., and Becker, K., 1992. Fracture permeability and alteration in gabbro from the Atlantis II Fracture Zone. In Hurst, A., Griffiths, C.M., and Worthington, P.F. (Eds.), Geological Applications of Wireline Logs II. Geol. Soc. Spec. Publ. London, 65:199-210.
Henstock, T.J., Woods, A.W., and White, R.S., 1993. The accretion of oceanic crust by episodic sill injection. J. Geophys. Res., 98:4143-4161.

Hey, R., 1977. Tectonic evolution of the Cocos-Nazca spreading center. Geol. Soc. Am. Bull., 88:1404-1420.

Hey, R., Johnson, G.L., and Lowrie, A., 1977. Recent plate motions in the Galapagos area. Geol. Soc. Am. Bull., 88:1385-1403.

Hurst, S.D., Karson, J.A., and Verosub, K.L., 1994. Paleomagnetism of tilted dikes in fast spread oceanic crust exposed in the Hess Deep Rift: implications for spreading and rift propagation. Tectonics, 13:789-802.

Karson, J.A., Hurst, S.D., and Lonsdale, P.F., 1992. Tectonic rotations of dikes in fast-spread oceanic crust exposed near Hess Deep. Geology, 20:685-688.

Kleinrock, M.C., and Hey, R.N., 1989. Migrating transform zone and lithospheric transfer at the Galapagos $95.5^{\circ} \mathrm{W}$ propagator. J. Geophys. Res., 94:13859-13878.

Lister, C.R.B., 1974. On the penetration of water into hot rock. Geophys. J. R. Astron. Soc., 39:465-509.

Lonsdale, P., 1977. Regional shape and tectonics of the equatorial East Pacific Rise. Mar. Geophys. Res., 3:295-315.

- 1988. Structural pattern of the Galapagos microplate and evolution of the Galapagos triple junction. J. Geophys. Res., 93:13551-13574.

, 1989. The rise flank trails left by migrating offsets of the equatorial East Pacific Rise axis. J. Geophys. Res., 94:713-743.

MacLeod, C.J., and Boudier, F., 1994. Melt transport in the lower oceanic crust at fast-spreading ridges: evidence from Hess Deep and the Oman ophiolite. Eos, 75:626.

MacLeod, C.J., Célérier, B., and Harvey, P.K., 1995. Further techniques for core reorientation by core-log integration: application to structural studies of the lower oceanic crust in Hess Deep, eastern Pacific. Sci. Drill., 5:77-86.

Mammerickx, J., and Smith, S.M., 1994. GEBCO Sheet 5.07. In GEBCO Digital Atlas: Merseyside, UK (Brit. Oceanogr. Data Centre).

McFadden, P.L., and Merrill, R.T., 1975. Geomagnetic secular variation over the past 5 m.y. Rev. Geophys. Space Phys., 13:687-708.

McKenzie, D.P., 1969. The relationship between fault plane solutions for earthquakes and the directions of the principal stresses. Bull. Seismol. Soc. Am., 59:591-601.

Mével, C., and Stamoudi, C., 1994. Serpentinization of the shallow mantle at a fast-spreading ridge (ODP Site 895 at Hess Deep, East Pacific Rise). Eos, $75: 650$

Nur, A., Ron, H., and Scotti, O., 1986. Fault mechanics and the kinematics of block rotations. Geology, 14:746-749.

Phipps Morgan, J., and Chen, Y.J., 1993. The genesis of oceanic crust: magma injection, hydrothermal circulation, and crustal flow. J. Geophys. Res., 98:6283-6297.

Porras, J.J., Wiggins, S.M., and Dorman, L.M., 1995. Microearthquake location at the Hess Deep. Eos, 76:S273.

Searle, R.C., and Francheteau, J., 1986. Morphology and tectonics of the Galapagos triple junction. Mar. Geophys. Res., 8:95-129.

Wiens, D.A., and Stein, S., 1984. Intraplate seismicity and stresses in young oceanic lithosphere. J. Geophys. Res., 89:11442-11464.

Wiggins, S.M., Canuteson, E.L., Dorman, L.M., Hildebrand, J.A., Cornuelle, B.D., Sauter, A.W., and Schreiner, A.E., 1993. Crustal structure at Hess Deep: seismic studies show high velocity in the intra-rift ridge and low velocity in the Deep. Eos, 74:666.

Date of initial receipt: 7 February 1995

Date of acceptance: 16 June 1995

Ms 147SR-032 


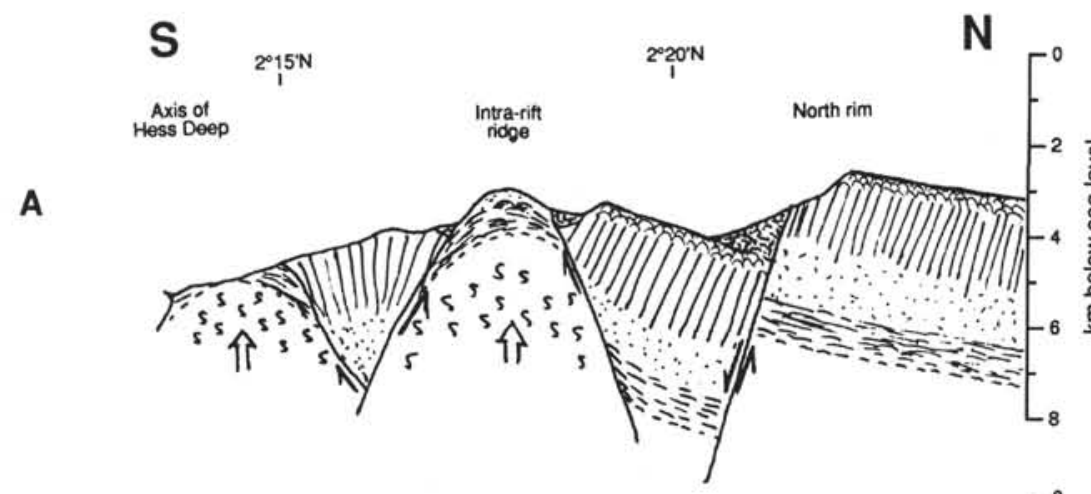

B

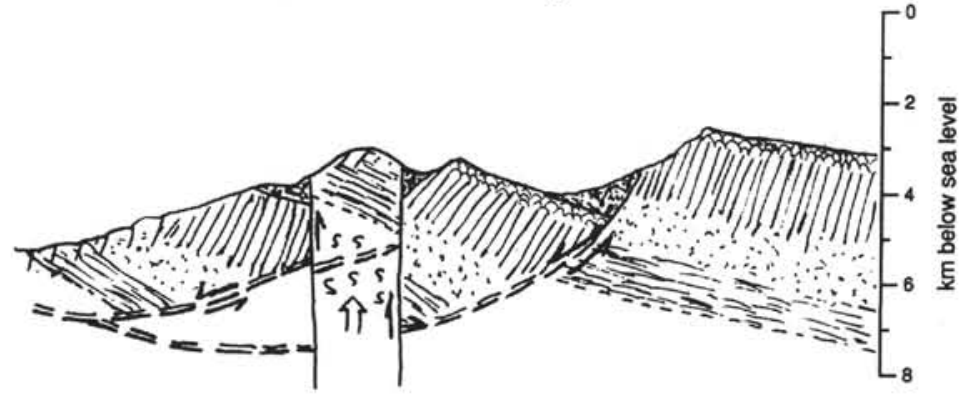

C
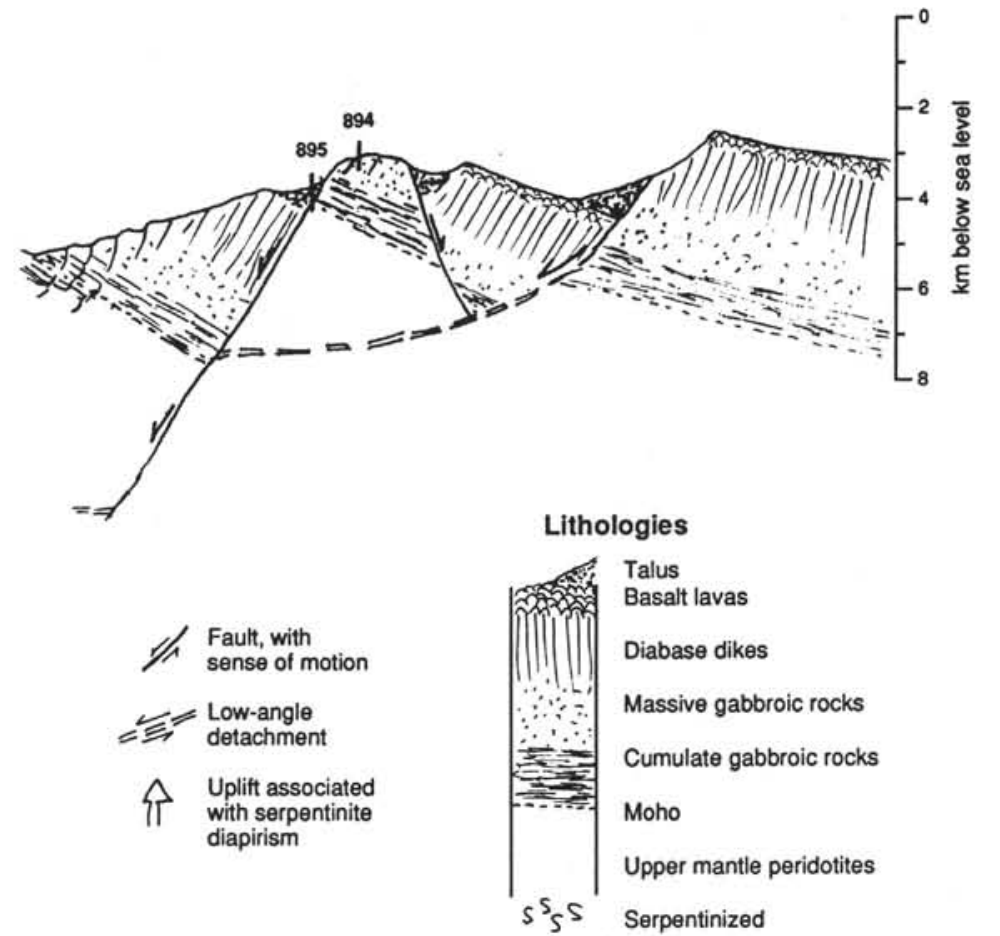

Figure 13. Interpretative two-dimensional sections across the central to northern part of Hess Deep, at longitude $101^{\circ} 32^{\prime} \mathrm{W}$. (A) and (B) are from Francheteau et al. (1990); (C) is proposed here on the basis of structural and paleomagnetic data from Leg 147. All sections are drawn with no vertical exaggeration, use realistic oceanic crustal thicknesses, and account for the observed topography and surface geology (as determined from submersible traverses: Francheteau et al., 1990). Model (A) implies that basal crustal layers have been uplifted by serpentinite diapirism and isostatic readjustment, whereas model (B) invokes low-angle normal faulting and rotation above a low-angle detachment, with only limited serpentinite diapirism to explain uplift of the intra-rift ridge. The model preferred here (C) is a variation of model (B) in that it, too, invokes northward rotation (from Leg 147 paleomagnetic data) and southward translation of crustal blocks above a low-angle detachment horizon; however, because of the evidence for static serpentinization at Site 895 (this paper) and high velocities below the intrarift ridge (Wiggins et al., 1993), diapirism is not believed to be the principal mechanism responsible for uplift of the ridge. Isolation and uplift of the intra-rift ridge can instead be achieved by internal deformation of the supra-detachment fault blocks (probably greater than shown here) and either "breakaway" of the fault block to the south of the ridge by means of relief on the detachment or, more likely, by later high-angle normal faulting (the intra-rift ridge is still seismically very active [Porras et al., 1995]). Uplift of the intra-rift ridge may have been aided by flexure upon unloading of the footwall; any buoyancy-related effects are likely to be in the form of uplift of coherent fault blocks only. Note that balancing of the cross-section is not necessarily required because of the likelihood of some strike-slip movement of lithospheric material into or out of the plane of the section. 